\title{
Natural recolonization and suburban presence of pumas (Puma concolor) in Brazil
}

\author{
Marcelo Mazzolli \\ Projeto Puma, R. Liberato Carioni 247, Lagoa da Conceição- Village III, 88062-205, Florianópolis-SC, Brazil. \\ E-mail: marcelo@projeto-puma.org. Tel: +55 49 3223-7971. Fax: +55 49 3251-1051.
}

Accepted 28 August, 2012

\begin{abstract}
The puma (Puma concolor, Carnivora: Felidae), extinct from considerable extensions of its former distribution, is considered threatened in south, southeast and northeast Brazil. Areas in the south and southeast have only recently been recolonized by the species, following decrease in logging activities after depletion of the Atlantic rainforest in the 1960s, and measures implemented since 1993 to protect this ecosystem. Data on recovery of puma populations was obtained from field observations based on the onset of depredation on sheep flocks in 1988, and also from the presence and growing number of records of pumas in urban and suburban areas since 2004. Logging bans caused a rural exodus since and also a 15 fold drop in the deforestation rate, creating conditions for a partial recovery of wildlife. Thirty-five records of puma were compiled demonstrating the historical presence of the species in the area prior to its temporary absence. Recent records included twenty-four cases in urban and suburban areas, and eleven of current breeding populations.
\end{abstract}

Key words: Araucaria forest, Atlantic forest, deforestation, Puma concolor, recolonization, recovery.

\section{INTRODUCTION}

The cases of natural recolonization in populations of large-bodied wild felids across large spatial scales are scarce in literature, as large felids are more prone to decline than to recover given the global and widespread loss of habitat integrity and direct persecution due to livestock depredation. If happening, recolonization is often limited to single locations (Harihar et al., 2011), or have been accomplished through reintroduction, some successfull others not (Breitenmoser et al., 2001; Hayward et al., 2007; Jule et al., 2008; Slotow and Hunter, 2009). Dramatic, country-wide changes in human attitude towards large cats, and hence on management in practice (either formal or informal) that could translate into population recovery, are not common. This is observed by the world-wide decline in the range of jaguars (Panthera onca), leopards (Panthera pardus), lions (Panthera leo), tigers (Panthera tigris) and cheetah (Acinonyx jubatus) (Nowell, 2009). In Brazil, as in the remaining of South America, lack of wide-scale data on distribution of pumas (Puma concolor) has prevented precise assessment of their population status (Laundré and Hernandéz, 2010). It is thus meaningfull that available information on distribution and status of puma be better organised to fulfill this gap in our current knowledge of the species. Such data will be unfolded here for the south (S) and southeast (SE) regions of Brazil, based on both historical and field data of the species and its habitat, while the recolonization patterns of pumas in this regions are also unwrapped.

The puma is considered endangered in the northeast, south and southeast regions of Brazil (Machado et al., 2008), having in fact lost considerable extensions of its former range in areas of higher human density, such as the eastern coast of Brazil (encompassing the easternmost areas of the mentioned regions). The puma is, however, far from being rare or uncommon in both $S$ and SE regions of Brazil, where the listing of pumas as endangered in $S$ and SE Brazil arises a suspition that its declared status is more of a result of a precautionary approach than the imminence of their extinction; perhaps a necessary precaution given the expressive decline undergone by the species in the past decades, as argued herein. Currently, however, the range of puma in Brazil is very broad, encompassing preserved terrestrial ecosystems (both in private and public lands) throughout the five regions of the country, widespread and often recorded in the areas where it is considered endangered; south (Azevedo, 2008; De Angelo et al., 2011; Mazzolli, 
1993, 2006, 2010; Mazzolli and Hammer, 2008; Pitman and Galvão, 2002; Vidolin et al., 2004) and southeast (Chiarello, 1999; Lyra-Jorge et al., 2009; Martins et al., 2008; Miotto et al., 2011).

Herein, the evidence of the retraction of range and posterior recolonization of pumas in $\mathrm{S}$ and $\mathrm{SE}$ regions of Brazil, over an area of $1,500,000 \mathrm{~km}^{2}$ was described. These results represent data from the only known recolonization event of a large wild felid in Brazil, which is also one of a few in the world. Its recolonization is likely a result of the cessation of uncontrolled logging in the Atlantic forest ecosystem, which currently enjoys a higher level of protection than any other continental ecosystem in Brazil. Although available in the literature, data with information relevant to describing puma recolonization in $S$ and SE Brazil have not been summarized so far and links between findings are incomplete to provide the whole scenario. This work, therefore, reviews the available information on puma status and recolonization in Brazil, setting the stage to argue, based on novel evidence, that the growing number of records of pumas in urban and suburban areas are an extension of the recolonizaton processs and range expansion in the country.

\section{Study area}

Climate and vegetation is not uniform throughout south (S) and southeast (SE) regions of Brazil. They all are, however, humid, with precipitation usually falling between the 1,200 to $2,000 \mathrm{~mm}$ range. Evergreen forest predominte by sea level, low altitudes, and coast mountains (such as Serra do Mar mountain range), displaying a westward transition to an ecosystem adapted to a cooler climate, consisting of coniferous forests intermingled with montane grasslands in the Tablelands, at altitudes prevailing between 900 to 1300 $\mathrm{m}$. Continuing westward, a semideciduous forest predominate. A latitudinal gradient of the habitats is also observed, with greater extensions of montane grasslands and coniferous forest in the south, and larger extensions of seasonal and of open and woodland savanna (known as Cerrado) to the north.

The Atlantic forest, highly regarded as one of the top global hotpspots of biodiversity and endemism (Myers et al., 2000), and one of the most threatened biomes in the world (Dinerstein et al., 1995), is in fact a mosaic of ecosystems that encompass most of the land area and vegetation as aforementioned, except for the extreme southern montane grasslands (Pampa) and the northern Cerrado. It also includes coastal vegetation such as scrubland, it is distributed in a land strip in the northeastern region, extending southward to encompass most of the land area of $S$ and SE regions. The Tablelands in the State of Santa Catarina (S Brazil) is the place where most of the direct information on recolonization of pumas was collected. It is dominated by the Araucaria Moist Forest, named after the dominat arboreal species, the Araucaria angustifolia, and considered an ecoregion of the Atlantic Forest (Dinerstein et al., 1995; WWF, 2001). Mean annual air temperatures range from 10 to $16^{\circ} \mathrm{C}$ (SEPLAN, 1991), in winter frequently reaching frosting conditions and in the colder days decreasing to minus $10^{\circ} \mathrm{C}$. Altitudes range from 800 - $1800 \mathrm{~m}$ and the climate is mesothermic humid in most of the region, with rainfall varying from 1,400 to $2,000 \mathrm{~mm}$ per annum (SEPLAN, 1991).

\section{METHODOLOGY}

Past records of puma during the presumpted period of declilne were obtained from museums (Mazzolli, 1992). Latter evidence were mainly skins and trophies obtained from ranchers and also depredation incidents (Mazzolli et al., 2002). To record the recolonization of pumas in the tablelands, ranches without historical records of losses to pumas were revisited in 2004-2005 to document recent depredation events (Mazzolli, 2006). The growing number of recent records of pumas in urban and suburban areas, were also considered evidence of recolonization by pumas. These were obtained from the author's personal handling of pumas captured or killed, and by records obtained from the news media, through internet search. Key words to retrieve information on pumas occurrence in urban and suburban areas were: the names of puma in portuguese (onça, suçuarana) combined with words in Portuguese for 'town' and 'urban', and names of south and southeast States (south: Rio Grande do Sul - RG; Santa Catarina SC; Paraná - PR; southeast: São Paulo - SP, Rio de Janeiro - RJ; Espírito Santo - ES; Minas Gerais - MG). Key words used to retrieve information of locations with presence of wild young pumas(to record current breeding populations) were 'young' and the names of puma, all in Portuguese. The retrieved reports were double-checked with additional searches, and used only if also available from known (and hence more reliable) sources, usually national media such as O Globo (2001), Globo (2009, 2010ª b, 2011), Estadão, Folha (2011), etc, thus avoiding reliance on personnal blogs or sites.

Additional searches were also often needed to obtain information of exact locations and street names. Locations were then searched in Google Earth (Google, Mountain View) using the name of streets or locality for aproximate coordinates in degree, minutes and seconds. A couple of times it was necessary to use Google maps instead, to identify the exact street location. Point locations in Google Earth were exported in KML format to be imported into TrackMaker (Geo Studio Tech., Belo Horizonte) containing a background map of Brazil. The file was then received final edition in Photoshop (Adobe, San Jose) and saved as JPG file. Field evidence of puma decline is given only for the Tablelands of Santa Catarina, whereas evidence of habitat empoverishment that may have driven decline, plus recolonization information by means of increased records, is given at a wider scale.

\section{RESULTS AND DISCUSSION}

\section{Known cases of puma recolonization}

In spite of few examples of natural recolonization of wild felids world-wide, cases of puma recolonization in the Americas have been reported and are briefly revised here. Unlike reintroductions, which are experimental and have reintroduced individuals geographically circunscribed to a known location, individuals in natural recolonizations are scattered over a large landscape and may not represent a breeding population (lone dispersers). Knowledge of natural recolonizations have often relied on fragmented and oportunistic information, 
such that many of the reports on this phenomena are not explicitly addressed in publications, but are a subset of information included on a broader report.

Enough evidence has been recently collected to support that the species is recolonizing the Midwest United States (LaRue et al., 2012). Pumas were considered absent from the Black Hills of South Dakota and Wyoming in Midwest United States from 1906 to 1930 (Anderson et al., 2004; Beier, 2010), and have increased in numbers enough to disperse long distances into presumed vacant ranges (Thompson and Jenks, 2005), with at least one new founding population recorded in the Badlands, North Dakota (NDGFD, 2007; Thompson et al., 2009; Thompson and Jenks, 2010). Puma is also believed to be recolonizing eastern United States (Hornocker and Negri, 2010; Pierce and Bleich, 2003; Thompson and Jenks, 2010), and moving east in Canada (Anderson Jr. et al., 2010). Records of puma in eastern US have, however, and regardless of the increasing number of public claims, have been considered inconsistent for lack of 'concrete physical evidence' (McCollough, 2011). Based on the lake of this evidence, the eastern subspecies of puma has been considered extinct and will likely be delisted from the Endangered Species Act (ESA) (McCollough, 2011). The decline of the eastern puma resulted from an early eradication police in the US that counted with official support and bounty payment (Nesslage et al., 2006). In Arizona, for example, on average 328 pumas were hunted annually as a pest for 51 consecutive years (from 1918 to 1969). In this State, pumas were also hunted from 1971 to 1987 as a game animal at an average rate of 235 per year (Smith, 1989), a harvest rate that has been stabilized and maintained (Day Jr, 2011). A wide scale recolonization of the species may be expected in the US due to changes in the species' protection status. In fact, and despite the fate of the eastern puma, dispersing individuals are already reaching Wisconsin and Michigan, and one (confimed by DNA analysis) dispersed as far as Connecticut, located by the Atlantic Ocean (Cat News, 2011; DEEP, 2011; Wisconsin Department of Natural Resources, 2011). Uncontested evidence of established populations at the wider scale are still lacking.

There is also evidence of puma recolonization in Uruguay and Patagonia, but information is fragmented, inadequate to provide a full understanding of the extent and intensity of these events. Recent records of pumas have been reported from Uruguay (Martínez et al., 2010), a country in which pumas were generally considered extinct. These reports may well be of persisting individuals from a once wide-ranging population, as the species is far from having radically changed its previous (uncommon and rare) status. Pumas in this country have unquestionably declined to near extinction, but isolated reports of single individuals had been available from time to time since long (Ximenez, 1972). Further, the species is rarely reported and is considered highly endangered (Martínez et al., 2010), thus not characterizing any substantial increase in numbers and in founding populations so far. Patagonian pumas are reported to have reduced their range in the past and would be currently occupying vacant range, following a decline in sheep business and associated reduction of rural human population (Walker and Novaro, 2010).

The most well documented case of population recolonization and expantion of the puma in the Americas is that of the Florida panther ( $P$. concolor coryi). The recovery of the Florida panther perhaps better illustrates what would be necessary for recovery of most of the world's threatened populations of large cats. It required intensive management intervention and population monitoring that extended for decades (United States Fish and Wildlife Service, 2006), culminating in the introduction of new DNA (through transfer of embryos) from a neighbouring puma population in Texas to relieve the inbreeding depression (Johnson et al., 2010). In spite of the apparent recovery, the core habitat of the Florida panther is currently restricted to 9,190 square kilometers (Kautz et al., 2006), fewer than 100 individuals remain in the wild, and their future is uncertain (Gross, 2005).

\section{Drivers of puma decline and recovery in the study area}

The precise period in which pumas went extinct in the tablelands is difficult to ascertain from direct evidence, mainly due to the widespread lack of wildlife monitoring in Brazil during the time when it must have happened. It is known that the jaguar ( $P$. onca), a sympatric predator of the puma, was last recorded (shot) in the tablelands by 1970 , and since then its disappearance wave spread over the adjoining areas (Mazzolli, 2009). Unlike the jaguar, currently with vestigial populations in $S$ and SE Brazil, pumas resisted, but it is not unlikely that the same pressure that caused jaguar retreat during this period may also have caused puma to decline in numbers.

Indirect evidence of the environmental impoverishment and overexploitation of the Atlantic forest that may have caused pumas and jaguars to decline are available. Large tracts of land had timber overexploited by the 1950s-1960s in SE (Dean, 1995) and by 1960s-1970s in the S (Thomé, 1995). In 1850, the State of São Paulo had $80 \%$ of its territory covered by forests, and in 1950 the forest had reduced to $18 \%$ (Rocha and Costa, 1998). In the tablelands of Santa Catarina, timber became scarce during the 1960s-1970s and a major economic crisis surfaced (Thomé, 1995). Besides the direct empoverishment of habitat, uncontrolled logging may have created conditions to an increase in hunting of wildlife in remote areas during logging peaks. As timber became scarce, villages were settled in remote and wild regions in search of new logging grounds, resulting that the environmental impact of logging was magnified by its association with human colonization. Local settlers, partially isolated from contact from food suppliers, certainly had to supplement their diet with wildlife and 


\section{South region}

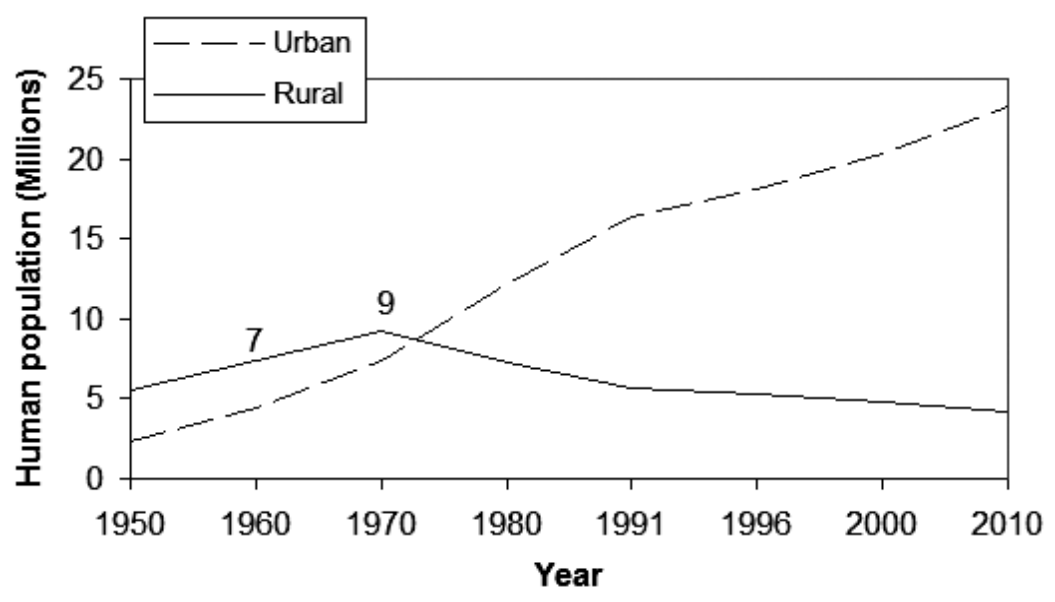

Southeast region

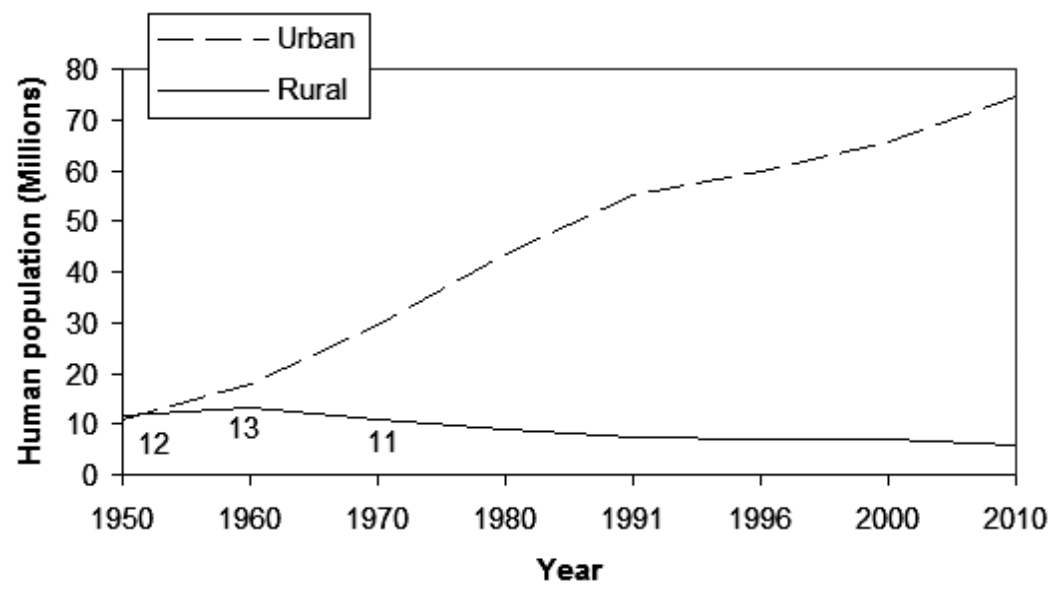

Figure 1. Human population demography in rural and urban areas from 1950 to 2010, showing peaks in rural areas during the 1960s (SE) and 1970s (S), corresponding with logging peaks in each region.

protect their livestock against predators. Poaching by itself is enough to cause substantial impact on wildlife populatons (Peres, 1996; Bennett and Robinson, 2000; Cullen Jr. et al., 2000, 2001), and certainly is magnified when coupled with deforestation. Pumas are still illegally shot nowadays in the $S$ and SE regions of Brazil (Mazzolli et al., 2002), the fact that they still persist may be explained by the absence of saw mills and its associated villages in remote places as before, and due to a steep decline in deforestation rates.

Once timber harvesting declined due to overexploitation, logging areas were abandoned, resulting in a rural exodus in the $S$ and $S E$ regions (Figure 1). The depletion of the most commercially valuable native timber by the 1960 s and 1970 s caused a slump in the overall exploitation of the forest. Some logging companies moved to the northern yet forested regions of Brazil and the others began to invest in forest plantations. That period of transformation brought a relief in forest exploitation that might have marked the beginning of the environmental recovery process that may have allowed pumas to expand to the areas they formerly occupied. About twenty years after the timber industry breakdown, a couple of other situations resulted in farther improvement of habitat conditions in S and SE Brazil. The first situation was the new and restrictive law of environmental crimes No. 9.605 issued in 1998, followed by a political enforcement to cohibit poaching through the Environmental Police.

The second situation was the release, on 10 February 1993, of the federal decree No. 750, granting full protection status to the Atlantic rainforest. At that time logging had declined but not stopped, and land was still freely cleared for plantations and for firewood. This document provoked a large commotion among those companies that harvested timber, manufactured furniture, produced charcoal, and used firewood to bake tiles, ceramics and bricks. The situation pushed these 


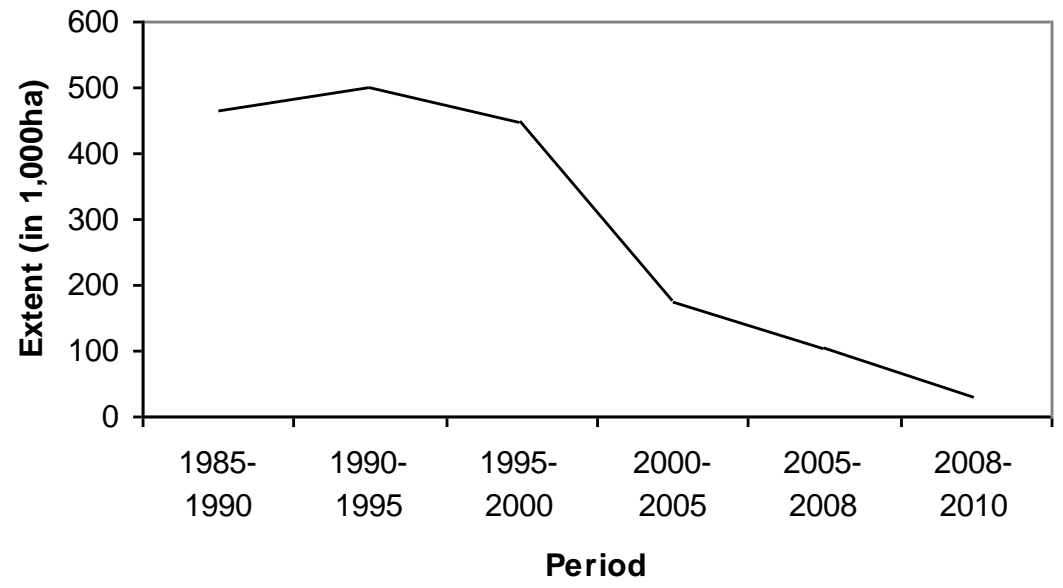

Figure 2. Line chart showing the decline in the rate of deforestation from 1985 to 2010, in hectares, for the entire Atlantic Forest. Data in Table 1 (appendix) (SOS Mata Atlântica, 2011a). See also data in Table 2 detailing deforestation rates for each State of the south and southeast regions (period 1995-2010) (SOS Mata Atlântica, 2003, 2009, 2011b).

companies to find alternative energy and timber sources and this, coupled with the depletion of the Atlantic Forest, pushed a large-scale development of plantation of fastgrowing exotic trees. The growth of forest plantations is illustrated by an increase in participation of exotic trees in the national round wood production, from $26,8 \%$ in 1990 to $65 \%$ in 2006 , with the largest share from the S and SE regions of Brazil (Bacha, 2008). The decline of available hardwood and then the prohibition of logging have released much of the pressure on the forest, reducing drastically the rate of deforestation (Figure 2) Prey populations are believed to have also shown signs of recovery after deforestation rates declined. Information is, however, scarce and largely non peer-reviewed. Much like the monitoring of pumas, counts of ungulates and other prey are just unavailable. Instead, the information on the increase in prey species are mentioned by field scientists as accounts (e.g. capybaras: Bellato et al., 2009; Dotta and Verdade, 2011), and are also divulged by the news media. It is important to mention that pumas in the neotropics prey on a large variety of species (Chinchilla, 1997; Emmons, 1987; Monroy-Vilchis et al., 2009), some of which should thrieve in secondary forests and/or modified landscapes once hunting pressure is released, particullarly the nine-banded armadillo (Dasypus novemcinctus), capybara (Hydrochaeris hydrochaeris) and gray brocket deer (Mazama gouazoubira). According to the report of Parry et al. (2007), secondary forests appear to support mammal abundances comparable with those of primary forest. In North America (e.g. Ackerman et al., 1984; Leopold and Krausman, 1986; Robinette et al., 1959) and Patagonia (Iriarte et al., 1991), the bulk of pumas often rely on few species. A broader prey choice in Neotropical regions enables the predator to shift to alternative prey when one of the major species suffers a significant decline in numbers. In $S$ Brazil, it was found that armadillos, a highly prolific species, may account for most of the biomass consumed (Mazzolli, 2000; Pitman and Galvão, 2002).

\section{Historical records of puma in the study area}

Pumas from $S$ and SE Brazil were long known to naturalists even before their reappearence and recovery. Linneus (1771) had assigned Brazil as type locality of $P$. concolor, based on a skull from the SE region (Nelson and Goldman, 1929), apparently sent by Ihering, a naturalist that had also recorded pumas in $S$ Brazil (Ihering, 1892). Goldman (1946) changed the type locality of puma to French Guiana and so far it has been maintained as such, which according to Hershkovits (1949) was based on an erroneous assumption (Mazzolli and Ryan, 1997). More recently, specimens from the museums 'Museu Nacional do Rio de Janeiro-RJ (MNRJ)', 'Museu de Zoologia da USP-SP (MZUSP)', 'Museu Homem do Sambaqui-SC (MHS), and 'Universidade Federal de Santa Catarina-SC (UFSC)' also demonstrates that pumas persisted in $S$ and $S E$ Brazil during the most critical period of logging and habitat deforestation, from 1960 to 1970 (Mazzolli, 1992) (Figure 3). Most of the specimens deposited at UFSC were collected by the author during field trips (Mazzolli, 1992; Mazzolli et al., 2002).

\section{Direct evidence of puma recolonization collected in S Brazil}

The first modern study on the ecology of pumas in Brazil was delivered from investigations carried out in the 


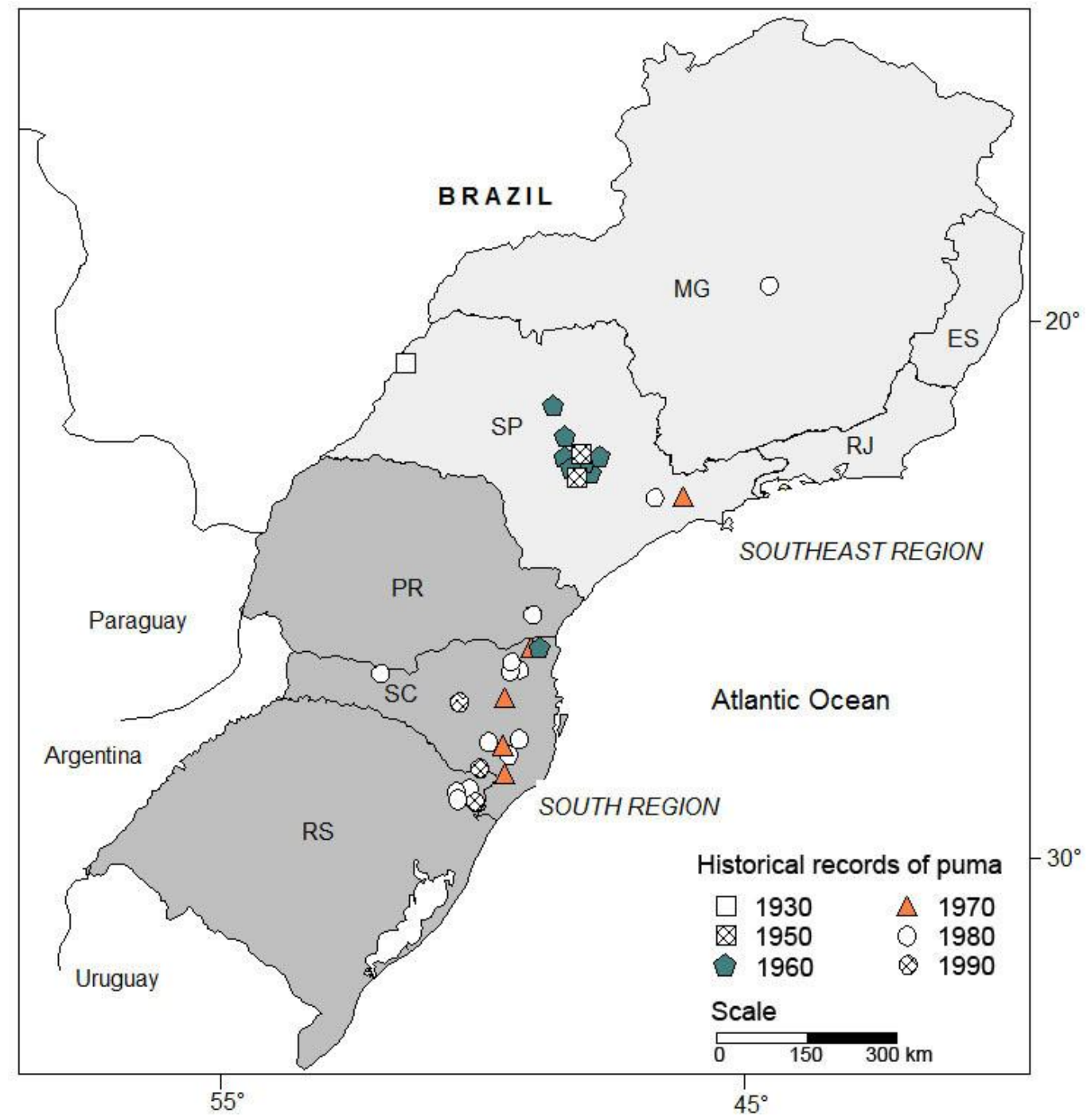

Figure 3. Historical records of pumas from 1930s to early 1990s in south and southeast Brazil. Collored symbols represent the critical period between 1960's and 1970's, period in which pumas may have declined as result of forest overexploitation. Data from Table 3 (appendix).

Brazilian midlle-west region, in the pantanal, designed to obtain information on jaguars (e.g. Crawshaw and Quigley, 1984; Schaller, 1983). Studies in the S region began soon after, when claims of livestock depredation begun to arrive at environmental agencies' desk, concomitantly in the States of Santa Catarina (Mazzolli and Da-Ré, 1988) and Paraná (Vidolin et al., 2004). In Santa Catarina (SC), pumas were often not considered as a native species by ranchers at the time. Ranchers, instead, perceived that either a predator had escaped a zoo or circus, or, soon after learning that our survey had a conservation bias, that the environmental agency was releasing (introducing) pumas in the wild. Interestingly, recolonizing pumas were also considered exotic species by locals in the neighbour State of Rio Grande do Sul (Marques and Ramos, 2003), and as far as Patagonia (Walker and Novaro, 2010). Rancher's were not aware of the puma presence until then, and this was the first indication that pumas had been wiped out and were recolonizing the area.

The survey in SC resulted in the first landscape study of the puma in Brazil, covering an area of four latitudinal by four longitudial degrees. Layers with hypsometric and vegetation maps, superimposed with puma records in 22 locations demonstrated that pumas were ranging mostly in pristine, mountaineous habitats (Mazzolli, 1993). The survey had begun in 1988 and extended up to 1995, resulting in the collection of 20 samples including skulls and pelts from ranchers that kept them as trophies (Mazzolli and Ryan, 1997; Mazzolli et al., 1997; Mazzolli et al., 2002). Pumas shot while attacking livestock, consisted of males, females, adult, subadults, and young. Latter, a larger sample of 37 skin samples from wild pumas poached after depredation was obtained by Castilho et al. (2011) during the period of 2005-2008.

Much has been learned on patterns of puma predation 


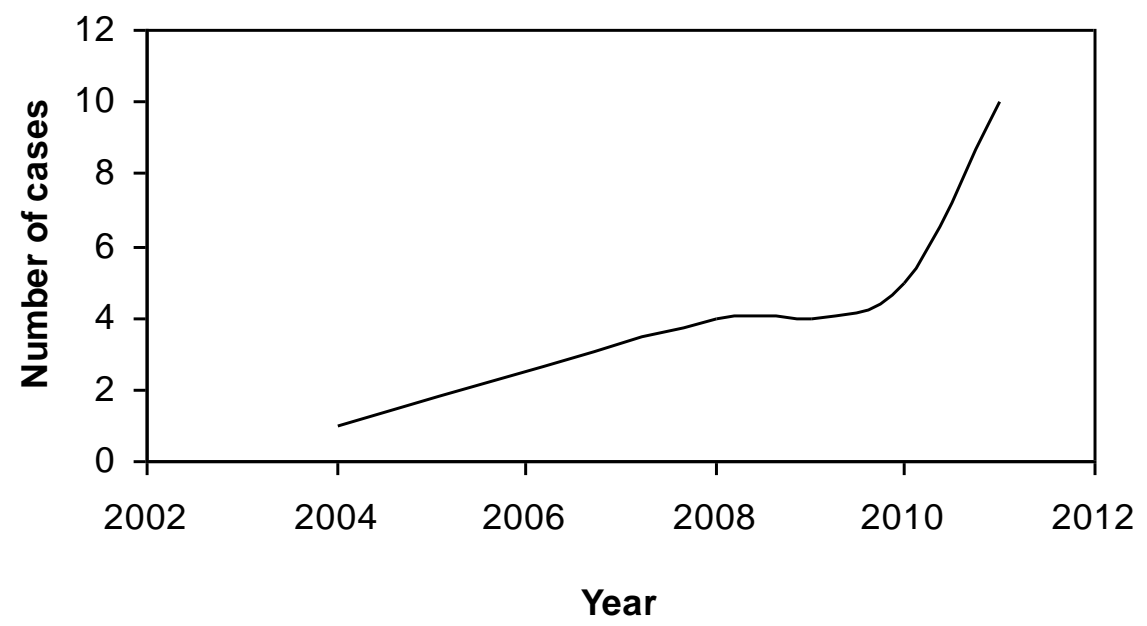

Figure 4. Increase in the number of pumas recorded in urban and suburban areas of south and southeast regions of Brasil. Details on Table 4 (appendix).

on livestock from the studies in SC. Sheep flocks were the most abundant vulnerable livestock, and were prior to puma recolonization, raised free-ranging, with only two out of twelve surveyed ranches having them corraled at night (Mazzolli et al., 1997). From that time onwards, ranches in the S region of Brazil weren't able to keep free-ranging sheep flocks in puma country any longer, as this would imply on depredation almost in a daily basis (Mazzolli et al., 2002). It has been estimated that this predator was responsible for the reduction of $70 \%$ of all sheep numbers in S Brazil, at least in the State of Santa Catarina (Mazzolli, 2005), forcing the purchase of sheep from extreme south Brazil (pampas grasslands) and from Uruguay to supply the meat market. The reduction in sheep flocks may be best explained by the unwillingness or inability of ranchers to keep large herds in fenced and safe areas rather than a direct product of depredation. As a result, ranchers simply reduced their herds to make them easily manageable during daytime grazing and nightime keeping in small corrals. Freeranging sheep in puma country turned unproductive due to the high number of losses compared to those flocks which were kept at nights in corrals (Mazzolli et al., 2002). It is thus assumed here that the early lack of ranchers' awareness of the presence of pumas, and lack of attacks to free - ranging sheep flocks that populated the landscape (Mazzolli et al., 1997) represent sufficient evidence of puma population reduction or absence before the recolonization process.

Furthermore, it is acknowledged that lack of depredation does not always mean that the predator is absent. Attacks by pumas are not uniformly distributed in a given area, and heterogeneity in spatial distribution of depredation may reach extremes exemplified by an entire flock being destroyed in few weeks, while neighbouring flocks are left unmolested for the duration of several years, as observed during the field studies mentioned above. However, it is also acknowledged that attacks will inevitably occur when flocks are available in large numbers across a wide landscape in puma country -and this is a main assumption - it implies that the absence of attacks indicate the absence of pumas, at least in the 'sheep-dominated landscape'. This assumption is supported by the behaviour of pumas in the tablelands of $S$ Brazil. Free-ranging sheep was predated at almost daily basis, whereas attacks to flocks corraled at night were occasional. There is no reason why pumas would not attack vulnerable and available free-ranging flocks, considering that the only reason to occasional and not systematic predation to corraled stock is explained by risk aversion due to proximity to households (Mazzolli et al., 2002). Further evidence of puma population recovery was collected from 2003 to 2005, during which ranches that had never had livestocked attacked suffered losses to puma, demonstrating that pumas were reaching areas further into open grasslands than previously recorded. At least two ranchers were known to keep free-ranging sheep in the grasslands for over 20 years up to 2004, with not a single depredation incident. When pumas moved in, attacks became frequent and ranchers had to move the herds to enclosures during the night (Mazzolli, 2006).

Statistics of puma occurrence are difficult to obtain in Brazil. Livestock depredation and occurrence of puma are officially recorded by a specialized center of the federal environmental agency (Cenap) centralized in São Paulo. It was founded in 1994, much at the same time when pumas were already showing up (Mazzolli, 1992, 1993; Mazzolli et al., 1997), thus unable to report cases prior to that. Lack of reliable voluntary information from the public obtained while granting permits for predator removal (Mansfield, 1997), or during compensation schemes (Wagner et al., 1997), as obtained elsewhere, limits the available information at the broad geographical scale. Country legislation do not allow any type of hunting or harvesting of wildlife in Brazil, and compensation scheme inexist (Verdade and Campos, 2004). Hard proof of puma presence at the wide scale has to be often 


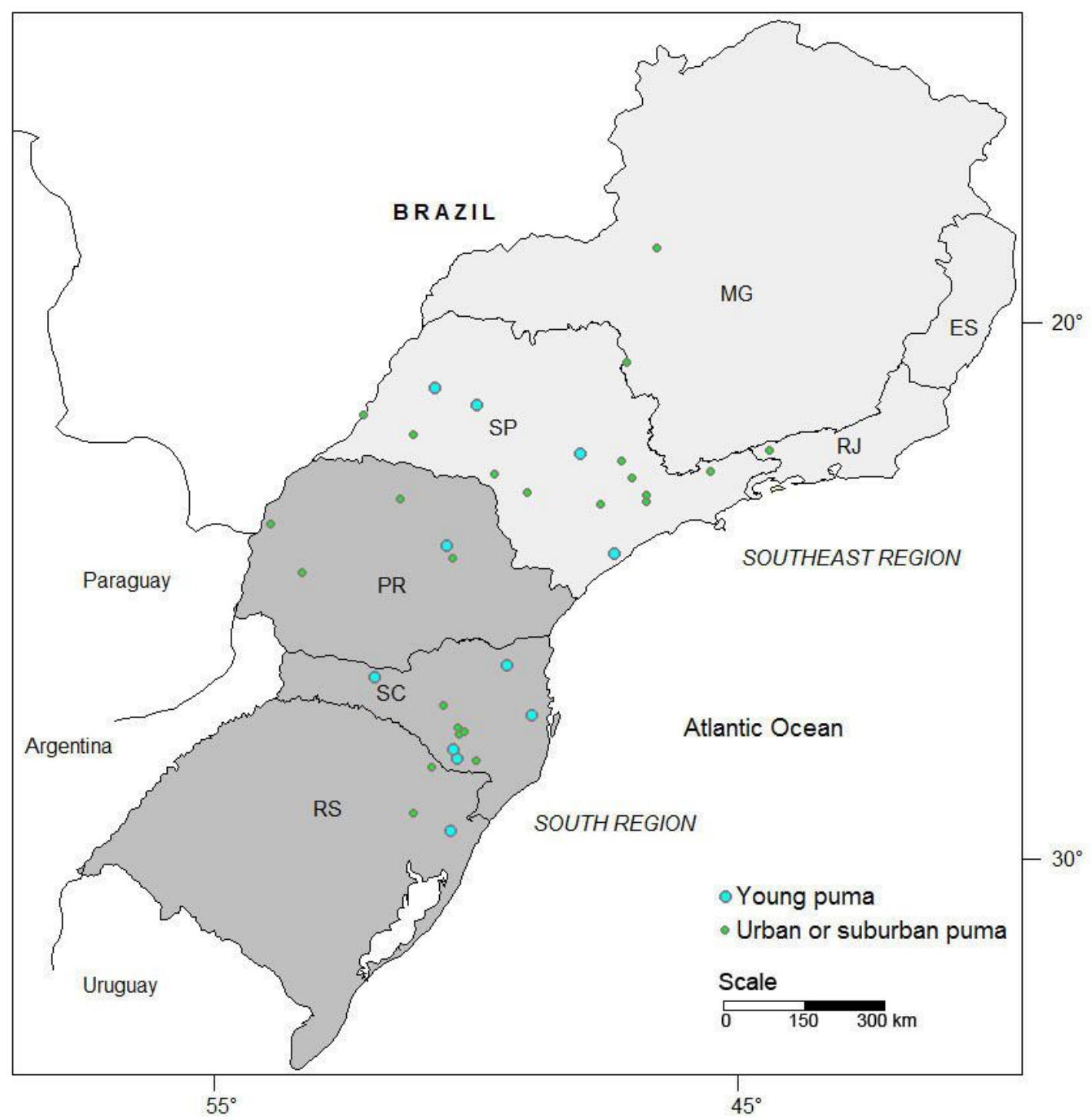

Figure 5. Location of puma occurrence sites in suburban and urban areas in south and southeast Brazil during the period 2004-2011, and records of young pumas from 1988-2011, demonstrating that pumas are reproductively active in the areas they have recolonized. Data from Tables 4 and 5 (appendix).

obtained from oportunistic information from the media or by (and this is hard to obtain) convincing ranchers to reveal their catch of poached pumas in their private properties, precluding any need for computer-intensive work to crunch large statistical databases on puma occurrence. In spite of that there is substantial evidence that recolonization expanded to urban and suburban areas following decline in deforestation, restraint of poaching, and sudden cases of puma depredation by the late 1980s and early 1990s. Pumas had not been recorded in urban areas prior to 2004, irrespectfully of the information source: news media, literature, or data collected directly by the author increasing in frequency since then (Figure 4). Records of pumas in urban and suburban areas were spatialized together with recent records of young wild pumas, to add to our understanding of distribution of cases and to compile evidence of breeding populations (Figure 5).

Prior to 2009, the Mata Ciliar Association, an NGO which maintains a Wildlife Rehabilitation Center since 1997, had never received claims of pumas in urban areas. From 2009 to 2010, the organization received eleven calls involving claims of pumas in the metropolitan area of Campinas alone (Crawshaw, 2011). The growing number of occurrence of pumas in urban areas are not conventionaly or consensually attributed to increase in numbers in the wild population, rather, it is often attributed by lay people as a result of urban expansion into the wilderness areas. However, large towns that may function as substantial barries to wildife dispersal represent only a fraction of the total landscape in the study area (IBGE, 2009), and except in high demographic 
concentrations of human population where pumas are known to be completely absent, such as most of the coastal plains of Santa Catarina and Rio Grande do Sul (Mazzolli, 1993), there is no reason to believe that pumas are in fact encrouched by urban expansion, not at least to a point of having to live in urban areas for lack of alternative habitat. Further, there is a well characterized human migration from rural to urban areas in $S$ and SE regions (IBGE, 2010) that may be resulting in a decrease, even if momentaneous, of human interference in puma habitats.

Another usual but easely disregarded argument is that pumas would be seeking towns because of lack of prey in the wild. In fact, if prey is scarce in wild habitats, it would not be more readly available in towns. Furthermore, pumas are not known to feed on garbage like oppossums, foxes, and coyotes, in such amounts that would allow them to have a sustainable diet (although they could make a service by eliminating stray dogs and cats). Instead, pumas have a territorial social structure, in which youngsters of about 20 months disperse to find their own territories (Anderson, 1983; Seindensticker et al., 1973). That means that as the number of individuals increase, they have to find territories outside those that are alredy owned by older individuals, a process that eventually will expand the total land area occupied by a given puma population accordingly. Should the population of pumas increase to a point of saturation in wilderness areas, pumas will then start occupying suboptimal habitats such as urban and suburban areas. The extent into which they can adapt to live in these environments, even if having to use hunting grounds in more suitable landscape, are not know, as pumas are sistematically removed or translocated when found near humans, (as in those cases reported here). Due to a recent change in public opinion, pumas are being tolerated near human dwellings in some areas of North America, allowing scientists to investigate novel aspects of puma-human interactions under such conditions (e.g. McKinney and Poppenberger, 2008; Knopf et al., 2011).

\section{CONCLUSION}

Unregulated logging and associated occupation of primitive areas by settlers are a plausible explanation to the decline of puma populations during the 1960s and 1970s. The economic crises from decrease in timber harvesting following forest overexploitation produced a release into habitat pressures that may have created conditions for puma recovery, an effect that was magnified by a rural migration of people to urban areas. This situation was latter enhanced by laws that enforced protection of the habitats and fauna. Pumas were shown not to have gone extinct from the landscape during the most critical periods of habitat modification in S and SE Brazil, between 1960 and 1970, likely surviving in small numbers in discrete patches, much like a metapopulation (Hanski and Simberloff, 1997). Although there was no evidence of breeding populations during that period, it is highly unlikely that individuals consisted entirely of dispersing individuals given the extent of the land area covered by these records.

Evidence of recolonization by pumas came from field studies at the Tablelands of S Brazil, during the periods 1988-1995 (Mazzolli, 1992; 1993; Mazzolli et al., 1997) and from 2004-2005 (Mazzolli, 2006). During the first period, sheep flocks were still raised free-ranging, and at first ranchers were not aware of what was striking their flocks. During the second period, large sheep flocks were no longer raised free-ranging due to the intensity of predation by pumas, ranchers all knew about the puma, which was now also reaching small flocks raised in less vulnerable areas farther from forests, in grasslands areas. During the 2004-2005 period, pumas further expanded their range by reaching vacant range in the rural landscape in the tablelands, begining also to show as road kills or in urban areas, with numbers of occurrence growing steadly since.

Finally, it should be added that a recent study of Tableland pumas found that this population has gone through a bottleneck (Castilho et al., 2011), corroborating the evidence of range reduction and posterior expansion as discussed. The recolonization of the puma was partially a product of the conservation policy that provided full protection status to the Atlantic forest. Policies such as those in which conservation decisions are made prior to ecosystem collapse may save millions, or even billions of dollars, that would otherwise be needed to be invested to recover species at the brink of extinction (such as the Florida panther mentioned above). The recolonization of pumas, however, should not be taken for granted. As human population continue to encroach natural areas causing habitat reduction and fragmentation, monitoring of threatened wildlife should be a priority, large-scale and continuous process supportive to decision-making at different management levels.

\section{REFERENCES}

Ackerman BB, Lindzey FG, Hemker TP (1984). Cougar food habits in southern Utah. J. Wildl. Manag. 48(1):147-155.

Ambiente Brasil (2010). Puma is rescued from trap in the town of São Paulo (Puma is rescued from trap in the town of São Paulo). AmbienteBrasil, $\quad$ February $3,2010$. http://noticias.ambientebrasil.com.br/clipping/2010/02/03/51627onca-parda-e-resgatada-de-armadilha-em-cidade-de-sp.html. Acessed December 19, 2011.

Anderson A (1983). A critical review of literature on puma (Felis concolor). Colorado Division of Wildlife, Wildlife Research Section, Special Report Number 54:91.

Anderson CR-Jr, Lindzey FG, Knopff KH, Jalkotzy MG, Boyce MS (2010). Cougar management in North America. In: Hornocker M and Negri S (eds.), Cougar ecology and conservation. University of Chicago Press, Chicago, Illinois, USA, pp. 41-56.

Anderson CR-Jr, Lindzey FG, McDonald DB (2004). Genetic structure of cougar populations across the Wyoming Basin: Metapopulation or megapopulation. J. Mammal. 85:1207-1214.

Augusto L (2004). Leão-baio capturado em bairro de Curitibanos (puma captured in the neighborhood of Curitibanos). A Notícia, Joinville, September 13, 2009 http://www.joinville.udesc.br/portal/noticias/clipping.php?id=328\&pg= 
50. Acessed 26 May 2011.

Azevedo FCC (2008). Food habits and livestock depredation of sympatric jaguars and pumas in the Iguaçu National Park area, south Brazil. Biotropica 40(4):494-500.

Bacha CJC (2008). Análise da evolução do reflorestamento no Brasil(Analysis of the evolution of forest plantations in Brazil). Rev. de Economia Agrícola São Paulo 55(2):5-24.

Beier P (2010). Cougars and conservation planning. In: Hornocker M and Negri S (eds.), Cougar ecology and conservation. University of Chicago Press, Chicago, Illinois, USA, pp. 177-189.

Bellato V, Souza AP, Sartor AA, Veiga LPHN, Centenaro F (2009). Occurrence of Fasciola hepatica in the population of capibaras (Hydrochaeris hydrochaeris) and in cattle (Bos taurus) in the municipality of Timbó, SC (Occurrence of Fasciola hepatica in the population of capibaras Hydrochaeris hydrochaeris and in cattle Bos taurus in the municipality of Timbó, SC). Revista de Ciências Agroveterinárias 8(1):66-70.

Bennett EL, Robinson JG (2000). Hunting for sustainability: the start of a synthesis. In: Robinson JG, Bennett EL (eds.), Hunting for sustainability in tropical forests. Columbia University Press, NY, pp. 499-520.

Bonato J (2011). Onça-parda invade quintal e é capturada por bombeiros (Puma invaded backyard and it is captured by fireman in the interior of São Paulo). UOL Notícias, July 7, 2011. http://noticias.uol.com.br/cotidiano/2011/07/26/onca-pardainvadequintal-e-e-capturada-por-bombeiros-no-interior-de-sp.jhtm. Acessed December, 2011.

Breitenmoser U, Breitenmoser-Würsten C, Carbyn LN, Funk SM (2001). Assessment of carnivore reintroductions. In: Gittleman JL, Funk SM, Wayne R, Macdonald D (eds), Carnivore Conservation. Cambridge University Press, Cambridge, pp. 241-281.

Castilho CS, Marins-Sa LG, Benedet RC, Freitas TO (2011). Landscape genetics of mountain lions (Puma concolor) in southern Brazil, Mammalian Biology - Zeitschrift fur Saugetierkunde 76(4):476-483.

Cat News (2011). Wisconsin's 'St. Croix cougar' killed in Connecticut. Cat News 55:44-45.

Chiarello AG (1999). Effects of fragmentation of the Atlantic forest on mammals communities in south-eastern Brazil. Biol. Conserv. 89:7182.

Chinchilla FA (1997). La dieta del jaguar (Panthera onca), el puma (Felis concolor) y el manigordo (Felis pardalis) en el Parque Nacional Corcovado, Costa Rica (The diet of jaguar Panthera onca puma Felis concolor and ocelot Felis pardalis (Carnivora: Felidae) in Parque Nacional Corcovado, Costa Rica). Rev. Biol. Trop. 45(3):1223-1229.

Correio Lageano (2008). Ambiental encontra puma atropelado na SC425 (Environmental police find puma hit by car in the SC-425 highway) April 17, 2008, Lages, Santa Catarina. Http://www.correiolageano.com.br/htmNoticia.php?id=9328\& $\quad \mathrm{c}=2$. Acessed August 10, 2011.

Correio Lageano (2009). Morte de um puma na SC-438 é um mistério para a polícia ambiental (death of puma in the SC-438 highway is a mistery for the environmental police), May 30, 2009, Lages, Santa Catarina. hp?id=19508\&c=3. Acessed August 10, 2011.

Correio de Lins (2006). Capturado filhote de onça vítima de queimadas (Puma kitten victim of wildfire was captured) Correio de Lins May 4, 2006, Lins, São Paulo. Http://www.correiodelins.com.br/cadernos/lernoticia_n.php?idnoticia= 1525. Acessed December 18, 2011.

Crawshaw PG (2011). Cosmos: história de uma onça urbana (Cosmos: the story of a urban puma). O Eco, May 6, 2011. Http://www.oeco.com.br/petercrawshaw/25008-cosmos-historia-deuma-onca-urbana. Acessed December 19, 2011.

Crawshaw PG, Quigley HB (1984). A ecologia do jaguar ou onçapintada no pantanal (The ecology of jaguar in the pantanal). Estudos bioecológicos do Pantanal, relatório final, parte 1. Instituto Brasileiro de Desenvolvimento Florestal (IBDF), Brasilia.

Cullen JL, Bodmer RE, Padua CV (2000). Effects of hunting in habitat fragments of the Atlantic Forests, Brazil. Biol. Conserv. 95:49-56.

Cullen JL, Bodmer RE, Padua CV (2001). Ecological consequences of hunting in Atlantic Forest patches, São Paulo, Brazil. Oryx. J. Fauna Flora Int. 35(2):137-144.

Cury T (2011). Onça morre ao ser capturada em Patos de Minas (Puma die after being captured in Patos de Minas). Clube Notícia, July 27,
2011. Http://www.clubenoticia.com.br/noticias/vernoticia/8121/oncamorreao-ser-capturada-em-patos-de-minas. Acessed December 19, 2011.

Day JRL (2011). Arizona mountain lion status report. In: Williams J, Robinson H, \& Sweanor L (eds), Proceedings of the 10th Mountain Lion Workshop, pp. 39. May 2-5, 2011. Bozeman, Montana.

De Angelo C, Paviolo A, Di Bitetti M (2011). Differential impact of landscape transformation on pumas (Puma concolor) and jaguars (Panthera onca) in the Upper Paraná Atlantic Forest. Divers. Distrib. 17(3):422-436.

Dean W (1995). With Broadax and Firebrand: The Destruction of the Brazilian Atlantic Forest. University of California Press, Berkley and Los Angeles, California.

DEEP (2011). Genetic testing reveals mountain lion killed in Milford originated in South Dakota: traveled to Conn. through Wis. and Minn. Department of Energy and Natural Resources, July 26 2011, Connecticut.http://www.ct.gov/dep/cwp/view.asp?Q=483778\&A=4013 Acessed 21 January, 2012.

Dinerstein E, Olson DM, Graham DJ, Webster AL, Primm SA, Bookbinder MP, Ledec G (1995). A conservation assessment of the terrestrial ecoregions of Latin America and the Caribbean. Washington, D.C, The World Bank.

Dotta G, Verdade LM (2011). Medium to large-sized mammals in agricultural landscapes of south-eastern Brazil. Mammalia 75(4):345352.

Emmons LH (1987). Comparative feeding ecology of felids in a neotropical rainforest. Behav. Ecol. Sociobiol. 20:271-283.

EPTV (2010). Morador encontra onça na garagem de casa (Local resident find puma in the garage of the house). EPTV, July7,2010.http://eptv.globo.com/noticias/NOT,0,0,308131,Morador+ encontra+onca+na+garagem+de+casa.aspx. Acessed December 20, 2011.

Folha (2011). Bombeiros capturam onça em loja no interior de SP (Fireman capture puma in a store in the interior of São Paulo) Folha, November 14, 2011. Http://f5.folha.uol.com.br/bichos/1006644bombeiros-capturam-oncaem- loja-no-interior-de-sp.shtml. Acessed December 19, 2011.

Globo (2009). Duas onças são capturadas no interior de SP em dois dias (two pumas are captured in the interior of São Paulo in the period of two days). Globo, March 31, 2009. http://g1.globo.com/Noticias/SaoPaulo/0,,MUL1066236-5605,00DUAS+ONCAS+SAO+CAPTURADAS+NO+INTERIOR+DE+SP+EM +DOIS+DIAS.html. Acessed December 19, 2011.

Globo $O$ (2011). Em SP, onça-parda invade quintal de casa e assusta morador (puma invaded a house backyard in São Paulo and frightened inhabitants). Jornal $\mathrm{O}$ Globo, São Paulo. Http://oglobo.globo.com/cidades/mat/2011/07/26/em-sp-onca-pardainvade-quintal-de-casa-assusta-moradores-924974887.asp. Acessed August 242011.

Globo (2010a). Onça se esconde em garagem de casa no interior de SP (puma hides in the garage of a house in the interior of São Paulo). Globo, November 3, 2010. Http://g1.globo.com/saopaulo/noticia/2010/11/onca-se-esconde-emgaragem-de-casa-nointerior-de-sp.html. Acessed December 19, 2011.

Globo (2010b). Onça parda é encontrada em fazenda em Resende (puma is found in a farm in Resende). Globo, April 2, 2010. Http://g1.globo.com/Noticias/Rio/0,,MUL1555105-5606,00ONCA+PARDA+E+ENCONTRADA+EM+FAZENDA+EM+RESENDE .html. Acessed December 20, 2010.

Globo (2011). Imagens de onça em Campos de Jordão deixa moradores e turistas preocupados (video of a puma in Campos de Jordão raise the concern of inhabitants and tourists). Sistema Globo de Televisão, São Paulo, December 18, 2011. Http://video.globo.com/Videos/Player/Noticias/0,,GIM1603190-7823IMAGENS+DE+ONCA+EM+CAMPOS+DE+JORDAO+DEIXA+MOR ADORES+E+TURISTAS+PREOCUPADOS,00.html. Acessed August 24, 2011.

Goldman EA (1946). Classification of the races of the puma, part 2. In: Young SP and Goldman EA (eds), The puma, mysterious american cat. American Wildlife Institution, Washington, D.C, pp. 177-302.

Gomes A (2006). Vítima de incêndio em canavial, filhote de onça vem para o zôo (Victim of a fire in a sugar cane plantation, puma kitten is taken to a zoo). Folha da Região, October 28, 2006,Araçatuba,SãoPaulo.http://www.folhadaregiao.com.br/Materia.p 
hp?id=58571. Acessed December 18, 2011.

Gomes P (2008). Leão-baio morre envenenado na Serra de SC (Puma die after being poisoned in the Tablelands of Santa Catarina) Diário Catarinense, November 7, 2008, Florianópolis, Santa Catarina.

Graipel ME (2010). As onças da minha família (the pumas of my family). As onças da minha família. Editora Herbário Barbosa Rodrigues, Itajaí, Santa Catarina.

Gross L (2005). Why not the best? How science failed the Florida panther. PLoS Biol 3(9):e333. doi:10.1371/journal.pbio.0030333.

Hanski I, Simberloff D (1997). The metapopulation approach, its history, conceptual domain, and application to conservation. In: Hanski I and Gilpin ME (eds.), Metapopulation Biology: ecology, genetics and evolution. Academic Press, San Diego, CA, pp. 5-26.

Harihar A, Pandav B, Goyal SP (2011). Responses of leopard Panthera pardus to the recovery of a tiger Panthera tigris population. J. Appl. Ecol. 48(3):806-814.

Hayward MW, Kerley GIH, Adendorff J, Moolman LC, O'Brien J, SholtoDouglas A, Bissett C, Moolman LC, Bean P, Fogarty A, Howarth D, Slater R and Kerley GIH (2007). The reintroduction of large carnivores to the Eastern Cape, South Africa: an assessment. Oryx 41(2):205-214.

Herskovitz P (1959). Type locality of Felis concolor concolor Linnaeus. Proc. Biol. Soc. Wash. 72:97-100.

IBGE (2009). Metropolitan regions (Metropolitan regions) Rio de Janeiro.

http://www.ibge.gov.br/ibgeteen/atlasescolar/mapas_pdf/brasil_regio es_metropolitanas.pdf. Acessed December 26, 2011.

IBGE (2010). XII Demographic acessment (XII Demographic assessment) SIDRA database, Instituto Brasileiro de Geografia e Estatística, Rio de Janeiro. http://www.sidra.ibge.gov.br. Acessed December 26, 2011.

Ihering HV (1892). The mammals of Rio Grande do Sul (The mammals of Rio Grande do Sul). An. Rio Grande do Sul 8:96-123.

Iriarte JA, Johnson WE, Franklin WL (1991). Feeding ecology of the Patagonia puma in southernmost Chile. Revista Chilena de Historia Natural 64:145-156.

Johnson WE, Onorato DP, Roelke, ME, Land ED, Cunningham M, Belden RC, McBride R, Jansen D, Lotz M Shindle D, Howard J, Wildt DE, Penfold LM, Hostetler JA, Oli MK, O'Brien SJ (2010). Genetic Restoration of the Florida Panther. Science 329(5999):1641-1645.

Jule KR, Leaver LA, Lea SEG (2008). The effects of captive experience in reintroduction survival in carnivores: a review and analysis. Biol. Conserv. 141(2):355-363.

Kautz R, Kawula R, Hoctor T, Comiskey J, Jansen D, Jennings D, Kasbohm J, Mazzotti F, McBride R, Richardson L, Root K (2006). How much is enough? Landscape-scale conservation for the Florida panther. Biol. Conserv. 130:118-133.

Knopf AA, Knopf KH, Boyce MS, St. Clair CC (2011). Cougars in the backyard: large carnivore conservation in developing landscape. In: Williams J, Robinson H, and Sweanor L (eds.), Proceedings of the 10th Mountain Lion Workshop. May 2-5, 2011. Bozeman, Montana, p. 193.

LaRue, MA, Nielsen, CK, Dowling, M, Miller, K, Wilson, B, Shaw, H, Anderson CR (2012). Cougars are recolonizing the midwest: Analysis of cougar confirmations during 1990-2008. J. Wildl. Manag. doi: 10.1002/jwmg.396.

Laundré J, Hernandéz L (2010). What we know about pumas in Latin America. In: Hornocker M and Negri S (eds.), Cougar ecology and conservation. University of Chicago Press, Chicago, Illinois, USA, pp.76-90.

Leitóles $F$ (2011). Onça é encontrada dentro de churrasqueira de casa de Corbélia pPuma is found in a barbecue structure within Corbélia). Gazeta do Povo, November 7, 2011. Http://www.gazetadopovo.com.br/vidaecidadania/conteudo.phtml?id= 1189430. Acessed December 19, 2011.

Leopold BD, Krausman PR (1986). Diets of 3 predators in Big Bend National Park, Texas. J. Wildl. Manag. 50:290-295.

Luporini $F$ (2010). Onça invade quintal de casa e é capturada em Arapongas (puma invades backyard and it is captured in Arapongas). Jornal de Londrina, August 16, 2010. http://www.jornaldelondrina.com.br/cidades/conteudo.phtml?tl=1\&id= 1036379\&tit=Onca-invade-quintal-de-casa-e-e-capturada-emArapongas. Acessed December 19, 2011.

Lyra-Jorge MC, Ribeiro MC, Ciocheti G, Tambosi LR, Pivello VR
(2009). Influence of multi-scale landscape structure on the occurrence of carnivorous mammals in a human-modified savanna, Brazil. Eur. J. Wildl. Res. 56(3):359-368.

Machado AB, Drumond GM, Paglia AP (2008). Livro vermelho da fauna brasileira ameaçada de extinção (Red book of the Brasilian fauna threatened with extinction) Ministério do Meio Ambiente, Brasília, D.F.

Mansfield TM (1997). Role of state widlife managing agencies in managing mountain lions. In: Harrison DJ and Chapin TG (eds.), Transactions of the 72nd North American Wildlife and Natural Resources Conference, pp. 217-224.

Marques, RV; Ramos, FM (2003). Uso de armadilhas fotográficas na determinação de aspectos da organização social de carnívoros na Floresta Nacional de São Francisco de Paula/IBAMA, RS (the use of camera traps to determine aspects of social organization of carnivores in the National Forest of São Francisco de Paula). Divul. Mus. Ciênc. Tecnol. UBEA/PUCRS, 8: 31-36.

Martínez JA, Rudolf JC, Queirolo D (2010). Puma concolor (Carnivora, Felidae) en Uruguay: situación local y contexto regional (Puma concolor (Carnivora, Felidae) in Uruguay: local situation and regional context). Mastozoología Neotropical 17: 153-159.

Martins R, Quadros J, Mazzolli M (2008). Hábito alimentar e interferência antrópica na atividade de marcação territorial do Puma concolor e Leopardus pardalis (Carnivora: Felidae) e outros carnívoros na Estação Ecológica de Juréia-Itatins, São Paulo (feeding habits and anthropic interference in the activity of territorial marking of Puma concolor and Leopardus pardalis (Carnivora: Felidae) and other carnivores in the Estação Ecológica de JuréiaItatins, São Paulo, Brazil). Rev. Bras. Zool. 25(3):427-435.

Mazzolli M (1992). Contribuição ao conhecimento da distribuição, identificação e conservação do puma (Felis concolor spp.) no Estado de Santa Catarina (contribution to the knowledge of distribution, identification, and conservation of the puma (Felis concolor spp.) in the State of Santa Catarina). Undergraduate dissertation. Universidade Federal de Santa Catarina, Florianópolis.

Mazzolli M (1993). Ocorrência de Puma concolor em áreas de vegetação remanescente do Estado de Santa Catarina (occurrence of Puma concolor in areas of remnant vegetation in the State of Santa Catarina). Revista Brasileira de Zoologia 10:581-587.

Mazzolli M (2000). A comparison of habitat use by the mountain lion (Puma concolor) and kodkod (Oncifelis guina) in the southern Neotropics with implications for the assessment of their vulnerability status. M.Sc. thesis. University of Durham, Durham, UK.

Mazzolli M (2005). Efeito de gradientes de floresta nativa em sistemas agroflorestais na diversidade de mamíferos vulneráveis (effects of forest gradients in agroforestry systems on the diversity of vulnerable mammals). Report of project coded CSR 283-2002, WWF, Brasilia.

Mazzolli M (2006). Persistência e riqueza de mamíferos focais em sistemas agropecuários no planalto meridional Brasileiro (persistence and richness of focal mammals in agroranching systems in southern Brazilian highlands). Ph.D. Thesis (in Portuguese). Universidade Federal do Rio Grande do Sul (UFRGS), Porto Alegre, Brazil.

Mazzolli M (2009). Loss of historical range of jaguars in southern Brazil. Biodivers. Conserv. 18(6):1715-1717.

Mazzolli M (2010). Mosaics of exotic forest plantations and native forests as habitat of pumas. Environ. Manag. 46:237-253.

Mazzolli M, Da-Ré MA (1988). Felis concolor: ocorrência de ataques a rebanho nas localidades de Rio dos Cedros e Ponte Cerrada, Estado de Santa Catarina, e Bom Jesus, Estado do Rio Grande do Sul (Felis concolor: occurrence of attacks on livestock in the localities of Rio dos Cedros and Ponte Serrada, State of Santa Catarina, and Bom Jesus, State of Rio Grande do Sul). Report (in Portuguese). Universidade Federal de Santa Catarina (UFSC) e Instituto Brasileiro de Meio Ambiente (IBAMA). Florianópolis, Santa Catarina.

Mazzolli M, Graipel ME, Dunstone N (2002). Mountain lion depredation in southern Brazil. Biol. Conserv. 105:43-51.

Mazzolli M. Hammer LA (2008). Qualidade de ambiente para a onçapintada, puma e jaguatirica na Baía de Guaratuba, Estado do Paraná, utilizando os aplicativos Capture e Presence (environmental quality for jaguar, puma, and ocelot in the Guaratuba bay, State of Paraná, using the programs Capture and Presence). Biotemas 21(2):105-117.

Mazzolli M, Ryan CB (1997). Contributions to the identification of Puma concolor concolor. In: Padley WD (ed.), Proceedings of the Fifth 
Mountain Lion Workshop. Research Report (full). 27 February to 1st of March, 1996, San Diego, CA. Southern California Chapter, The Wildlife Society, California Department of Fish and Game, California, pp. 46-53.

Mazzolli M, Ryan CB, Graipel ME (1997). Effects and patterns of mountain lion predation of livestock on small and medium sized properties in Santa Catarina, Brazil. In: Padley WD (ed.), Proceedings of the Fifth Mountain Lion Workshop. Research Report (full). 27 February to 1st of March, 1996, San Diego, CA. Southern California Chapter, The Wildlife Society, California Department of Fish and Game, California, pp. 54-61.

McCollough M (2011). Eastern puma (=cougar) (Puma concolor couguar) 5-YEAR REVIEW: Summary and Evaluation. U.S. Fish and Wildlife Service. Orono, Maine.

McKinney T, Poppenberger S (2008). Distribution and movements of mountain lions associated with human residential/urbanized areas in north-central Arizona. In: Toweill DE, Nadeau S, and Smith D (eds.), Proceedings of the Ninth Mountain Lion Workshop May 5-8, 2008, Sun Valley, Idaho, p. 110.

Miotto RA, Cervini M, Begotti RA, Galetti Jr. PM (2011). Monitoring a puma (Puma concolor) population in a fragmented landscape in southeast Brazil. Biotropica. doi: 10.1111/j.1744-7429.2011.00772.x.

Monroy-Vilchis O, Gómez Y, Janczur M, Urios V (2009). Food Niche of Puma concolor in Central Mexico. Wildl. Biol. 15(1):97-105.

Myers N, Mittermeier RA, Mittermeier CG, Fonseca GAB, Kent J (2000). Biodiversity hotspots for conservation priorities. Nature 403:853-858.

Nelson EW, Goldman EA (1929). List of pumas, with three described as new. J. Mammal. 10(4):345-350.

Nesslage GM, Wilberg MJ, Riley SJ (2006). Rates and spatial patterns of decline in historical cougar and wolf populations in Montana. Intermt. J. Sci. 12:63-76.

North Dakota Game and Fish Department (2007). Status of mountain lion management in North Dakota. North Dakota Game and Fish Department, Bismarck, North Dakota, USA.

Nowell K (2009). Felidae: status and conservation. In: Wilson DE, Mittermeier RA, Ruff S, Martinez-Vilalta A, Hoyo D (eds.), Handbook of the Mammal of the World. Volume 1. Carnivora. Lynx Edicions with IUCN and Conservation International, Barcelona.

Nunes O (2008). Onça aparece em árvore e assusta moradores (puma appear on a tree and frightens inhabitants (in Portuguese). Gazeta do Povo, October 14, 2008. Http://www.gazetadopovo.com.br/vidaecidadania/conteudo.phtml?id= 817706. Acessed December 19, 2011.

Olson DM, Dinerstein E, Wikramanayake ED, Burgess ND, Powell GVN, Underwood EC, D'Amico JA, Itoua I, Strand HE, Morrison JC, Loucks CJ, Allnutt TF, Ricketts TH, Kura Y, Lamoreux JF, Wettengel WW, Hedao P, Kassem KR (2001).Terrestrial ecoregions of the world: A new map of life on earth. Bioscience 51(11):933-938.

Parry L, Barlow J, Peres CA (2007). Large-vertebrate assemblages of primary and secondary forests in the Brazilian Amazon. J. Trop. Ecol. 23:653-662.

Peres CA (1996). Population status of white-lipped Tayassu pecari and collared peccaries $T$. tajacu in hunted and unhunted amazonian forests. Biol. Conserv. 77:115-123.

Pierce BM, Bleich VC (2003). Mountain Lion (Puma concolor). In: GA Feldhammer, Thompson BC, and Chapman JA (eds), Wild Mammals of North America: biology, management, and conservation, 2 nd edition. The Johns Hopkins University Press, Baltimore, Maryland, USA, pp. 744-757.

Pitman, MRPL, Galvão F (2002). El Jaguar, el puma y el hombre en tres áreas protegidas del bosque atlántico costero de Paraná, Brasil. In: Medellín RA, Equihua C, Chetkiewicz CLB, Crawshaw Jr. PG, Rabinowitz A, Redford KH, Robinson JG, Sanderson E, Taber A (eds). El jaguar en el nuevo milenio: una evaluación de su condición actual, historia natural y prioridades para su conservación. Prensa de la Universidad Nacional Autônoma de México/Wildlife Conservation, Ciudad de Mexico, Mexico, pp. 237-250.

Robinette WL, Gashwiler JS, Morris OW (1959). Food habits of the cougar in Utah and Nevada. J. Wildl. Manag. 23:261-273.

Rocha AA, Costa JP de O (1998). A Reserva da biosfera da Mata Atlântica e sua aplicação no Estado de São Paulo. Terra Virgem, Secretaria do Meio Ambiente do Estado de São Paulo, São Paulo. Schaller GB (1983). Mammals and their biomass on a Brazilian ranch. Arq. Zool. São Paulo 31(1):1-36.
Seidensticker JC, Hornocker MG, Wiles WV, Messick JP (1973). Mountain lion social organization in the Idaho Primitive Area. Wildl. Monogr. 35:1-60.

SEPLAN (1991). Atlas escolar de Santa Catarina. Secretaria de Estado de Coordenação Geral e Planejamento, Sub-secretaria de Estudos Geográficos e Estatísticos. Florianópolis, Santa Catarina, Brasil.

Shaw H (2010). Death of a towncat. In: Hornocker, M., Negri, S. (eds.) Cougar: ecology and management. 2010. The University of Chicago Press, Chicago.

Silva (2011). Onça aparece em área urbana de Tibagi. Gazeta do Povo, October 25, 2011. http://www.gazetadopovo.com.br/vidaecidadania/conteudo.phtml?tl=1 \&id=1184580\&tit=Onca-aparece-em-area-urbana-de-Tibagi- . Accessed December 19, 2011.

Slotow R, Hunter LTB (2009). Reintroduction Decisions Taken at the Incorrect Social Scale Devalue their Conservation Contribution: The African Lion in South Africa. In: Hayward MW and Somers MJ (eds.), Reintroduction of Top-Order Predators. Wiley-Blackwell, Oxford, UK, pp. 43-71.

Smith RH (ed.) (1989). Proceedings of the Third Mountain Lion Workshop, December 6-8 (1988); Arizona Game and Fish Department, Prescott, Arizona.

SOS Mata Atlântica (2003). Atlas dos remanescentes florestais da Mata Atlântica, período 1995-2000. Fundação SOS Mata Atlântica e Instituto Nacional de Pesquisas Espaciais, São José dos Campos.

SOS Mata Atlântica (2009). Atlas dos remanescentes florestais da Mata Atlântica, período 2005-2008. Fundação SOS Mata Atlântica e Instituto Nacional de Pesquisas Espaciais, São Paulo.

SOS Mata Atlântica (2011a). Novos dados do Atlas da Mata Atlântica, May 26, 2011. Fundação SOS Mata Atlântica, São Paulo. http://www.sosma.org.br/index. php?section=content\&action=content Details\&idContent=807. Accessed 24 December 2011.

SOS Mata Atlântica (2011b). Atlas dos remanescentes florestais da Mata Atlântica, período 2008-2010. Fundação SOS Mata Atlântica e Instituto Nacional de Pesquisas Espaciais, São Paulo.

Spigliatti S (2011). Onça é vista em árvore em Franco da Rocha-SP. Estadão, September 27, 2011. http://www.estadao.com.br/noticias/cidades,onca-e-vista-em-arvoreem-franco-da-rocha-sp,778289,0.htm. Accessed December 20, 2011.

Thomé N (1995). Ciclo da madeira: história da devastação da Floresta da Araucária e do desenvolvimento da indústria da madeira em Caçador e na Região do Contestado no século XX. Impressora Universal Gráfica e Editora in Caçador, Santa Catarina, Brasil.

Thompson DJ, Fecske DM, Jenks JA, Jarding AR (2009). Food habits of recolonizing cougars in the Dakotas: prey obtained from prairie and agricultural habitats. Am. Midl. Nat. 161:69-7.

Thompson DJ, Jenks JA (2005). Long-distance dispersal by a subadult male cougar from the Black Hills, South Dakota. J. Wildl. Manag. 69(2):818-820.

Thompson DJ, Jenks JA (2010). Dispersal movements of subadult cougars from the Black Hills: the notions of range expansion and recolonization. Ecosphere 1(4):art8. doi:10.1890/ES10-00028.

Tomazela JM (2009). Onça é capturada dentro de condomínio no interior de SP. Estadão, March 31, 2009 http://www.estadao.com.br/noticias/geral,onca-e-capturada-dentrode-condominio-no-interior-de-sp,347771,0.htm. Accessed December 19, 2011.

Tomazela JM (2011). Onça-parda é capturada em camping de AvaréSP. Estadão, November 03, 2011. http://www.estadao.com.br/noticias/geral,onca-parda-e-capturadaem-camping-de-avare-sp,794209,0.htm. Accessed December 19, 2011.

United States Fish and Wildlife Service (2006). Technical/ Agency Draft, Florida Panther Recovery Plan (Puma concolor coryi), Third Revision. U.S. Fish and Wildlife Service, Atlanta, Georgia, USA.

Valota (2011). Onça invade quintal de residência na zona norte de SP. Estadão, October 13, 2011. http://www.estadao.com.br/noticias/cidades,onca-invade-quintal-deresidencia-na-zona-norte-de-sp,784775,0.htm. Accessed December 19, 2011.

Verdade LM, Campos CB (2004). How much is a puma worth? Economic compensation as an alternative for the conflict between wildlife conservation and livestock production in Brazil. Biota Neotropica 4 (2), 
http://www.biotaneotropica.org.br/v4n2/pt/download?article+BN02204 022004+abstract. Accessed December 25, 2011.

Victória C (2008). Leão baio é avistado em Caxias do Sul. ClickRBS, Grupo RBS, Porto Alegre.

Vidolin GP, Moura Britto M, Braga FG, Filho AC (2004). Avaliação da predação a animais domésticos por felinos de grande porte no Estado do Paraná: implicações e estratégias. Cadernos da Biodiversidade (IAP). 4(2):50-58.

Vieira S (2009). Leão-baio é encontrado morto em Canela. Jornal Pioneiro May 12, 2009, Caxias do Sul. http://www.clicrbs.com.br/pioneiro/rs/plantao/10,2507425, Leao-baioe-encontrado-morto-em-Canela.html. Accessed May 262011.
Wagner KK, Schmidt RH, Conover MR (1997). Compensation programs for wildlife damage in North America. Wildl. Soc. Bull. 25:312-319.

Walker S and Novaro A (2010). The world's southernmost pumas in Patagonia and southern Andes. In: Hornocker M and Negri S (eds.), Cougar ecology and conservation. University of Chicago Press, Chicago, Illinois, USA. pp. 91-99.

WWF (2001). Araucaria Moist Forest (NT0101).

Ximenez A (1972). Notas sobre félidos neotropicales IV. Puma concolor ssp. en el Uruguay. Neotrópica 18(55):37-39. 


\section{APPENDIX}

Table 1. Extent of deforestation in the Atlantic Forest of Brazil by period.

\begin{tabular}{lc}
\hline Period & Extent (ha) \\
\hline $1985-1990$ & 466.937 \\
$1990-1995$ & 500.317 \\
$1995-2000$ & 445.952 \\
$2000-2005$ & 174.828 \\
$2005-2008$ & 102.938 \\
$2008-2010$ & 31.195 \\
\hline
\end{tabular}

Table 2. Extent of deforestation in the Atlantic Forest of south and southeast regions of Brazil by period, excluding Restinga (beach forest) and Mangroves.

\begin{tabular}{lcccc}
\hline \multirow{2}{*}{ States } & \multicolumn{4}{c}{ \% Deforestation by period } \\
\cline { 2 - 5 } & $\mathbf{1 9 9 5 - \mathbf { 2 0 0 0 }}$ & $\mathbf{2 0 0 0 - \mathbf { 2 0 0 5 }}$ & $\mathbf{2 0 0 5 - \mathbf { 2 0 0 8 }}$ & $\mathbf{2 0 0 8 - \mathbf { 2 0 1 0 }}$ \\
\hline South region & & & & \\
Rio Grande do Sul & 0.52 & 0.30 & 0.31 & 0.18 \\
Santa Catarina & Not available & 2.03 & 1.19 & 0.17 \\
Paraná & 4.34 & 1.44 & 0.51 & 0.17 \\
& & & & \\
Southest region & & & & \\
São Paulo & 1.65 & 0.18 & 0.11 & 0.02 \\
Rio de Janeiro & 0.48 & 0.07 & 0.13 & 0.03 \\
Espírito Santo & 1.19 & 0.16 & 0.12 & 0.05 \\
Minas Gerais & 2.80 & 1.46 & 1.23 & 0.45 \\
\hline
\end{tabular}




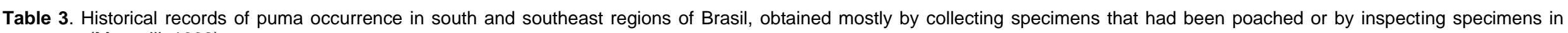
museums (Mazzolli, 1992).

\begin{tabular}{|c|c|c|c|c|c|c|}
\hline Locality & Town/State & $\begin{array}{l}\text { Approximate } \\
\text { coordinates }\end{array}$ & Type of record & Sex & Museum-number & Date \\
\hline \multicolumn{7}{|l|}{ South region } \\
\hline- & Urubici/ SC & $\begin{array}{l}28^{\circ} 01^{\prime} 38^{\prime \prime S} \\
49^{\circ} 36^{\prime} 45^{\prime \prime W}\end{array}$ & Mounted specimen & - & MHS-no \# & 1970 \\
\hline- & Urupema/ SC & $\begin{array}{l}27^{\circ} 57^{\prime} 59^{\prime \prime S} \\
49^{\circ} 51^{\prime} 42^{\prime \prime W}\end{array}$ & Skull & Female & UFSC-0351 & $\sim 1984$ \\
\hline Estr. Dona Francisca & Joinville/ SC & $\begin{array}{l}26^{\circ} 16^{\prime} 34 " S \\
49^{\circ} 02 ' 05^{\prime \prime W}\end{array}$ & Skull & Female & UFSC-0381 & $\sim 1976$ \\
\hline Alto Palmeiras & Rio dos Cedros/ SC & $\begin{array}{l}26^{\circ} 33^{\prime} 02^{\prime S} \\
49^{\circ} 22^{\prime} 56^{\prime \prime W}\end{array}$ & Skull & Male & UFSC-0318 & 1982 \\
\hline- & Bom Jesus/ RS & $\begin{array}{l}28^{\circ} 47^{\prime} 36 " \mathrm{~S} \\
50^{\circ} 14^{\prime} 34^{\prime \prime} \mathrm{W}\end{array}$ & Skull an pelt & Male & UFSC-0344 & 1987 \\
\hline- & Urubici/ SC & $\begin{array}{l}28^{\circ} 08^{\prime} 23^{\prime \prime S} \\
49^{\circ} 28^{\prime} 32^{\prime \prime W}\end{array}$ & Skull and pelt & Male & UFSC-0387 & 1989 \\
\hline- & Alfredo Wagner/ SC & $\begin{array}{l}27^{\circ} 48^{\prime} 45^{\prime \prime S} \\
49^{\circ} 20^{\prime} 20 " \mathrm{~W}\end{array}$ & Skull & Male & UFSC-0557 & 1990 \\
\hline- & Joinville/ SC & $\begin{array}{l}26^{\circ} 11^{\prime} 59 " \mathrm{~S} \\
48^{\circ} 58^{\prime} 59 " \mathrm{~W}\end{array}$ & Skull & Male & UFSC-0559 & 1969 \\
\hline- & Lontras/ SC & $\begin{array}{l}27^{\circ} 09^{\prime} 02^{\prime \prime S} \\
49^{\circ} 34^{\prime} 40^{\prime \prime} \mathrm{W}\end{array}$ & Skull & Male & UFSC-0386 & 1979 \\
\hline- & Siderópolis/SC & $\begin{array}{l}28^{\circ} 32^{\prime} 52^{\prime \prime S} \\
49^{\circ} 33^{\prime} 00^{\prime \prime} \mathrm{W}\end{array}$ & Skull & Male & UFSC-0319 & $\sim 1973$ \\
\hline- & Alfredo Wager/ SC & $\begin{array}{l}27^{\circ} 50 ' 21 " \mathrm{~S} \\
49^{\circ} 27^{\prime} 52^{\prime \prime W}\end{array}$ & Skull & Male & Private & 1990 \\
\hline Tainhas & Cambará do Sul/ RS & $\begin{array}{l}29^{\circ} 00^{\prime} 43^{\prime \prime S} \\
50^{\circ} 07^{\prime} 48^{\prime \prime W}\end{array}$ & Skull & Female & UFSC-0605 & 1998 \\
\hline Alto Palmeiras & Rio dos Cedros/SC & $\begin{array}{l}26^{\circ} 37^{\prime} 41^{\prime \prime S} \\
49^{\circ} 17^{\prime} 45^{\prime \prime W}\end{array}$ & Skull & Female & UFSC-0320 & Prior to 1988 \\
\hline Alto Palmeiras & Rio dos Cedros/ SC & $\begin{array}{l}26^{\circ} 39^{\prime} 29^{\prime S} \\
49^{\circ} 26^{\prime} 37^{\prime \prime W}\end{array}$ & Skull & Female & UFSC-0352 & 1988 \\
\hline- & Curitibanos/ SC & $\begin{array}{l}27^{\circ} 11^{\prime} 20^{\prime \prime S} \\
50^{\circ} 26^{\prime} 20^{\prime \prime} \mathrm{W}\end{array}$ & Skull and pelt & Female & Private & 1991 \\
\hline
\end{tabular}


Table 3. Continued.

\begin{tabular}{|c|c|c|c|c|c|c|}
\hline - & São Joaquim/ SC & $\begin{array}{l}28^{\circ} 23^{\prime} 25^{\prime \prime S} \\
50^{\circ} 00^{\prime} 39^{\prime \prime W}\end{array}$ & Skull and pelt & Female & UFSC-0606 & 1991 \\
\hline - & Ponte Serrada/ SC & $\begin{array}{l}26^{\circ} 37^{\prime} 11^{\prime \prime S} \\
51^{\circ} 54^{\prime} 19^{\prime \prime W}\end{array}$ & Skull and pelt & Female & UFSC-0333 & 1986 \\
\hline - & Jaquirana/ RS & $\begin{array}{l}28^{\circ} 54^{\prime} 36^{\prime \prime S} \\
50^{\circ} 18^{\prime} 59^{\prime \prime} \mathrm{W}\end{array}$ & Skull and pelt & Female & UFSC-0397 & 1989 \\
\hline - & Alfredo Wagner/ SC & $\begin{array}{l}27^{\circ} 52^{\prime} 04^{\prime \prime S} \\
49^{\circ} 19^{\prime} 25^{\prime \prime} \mathrm{W}\end{array}$ & Skull and pelt & Female & UFSC-0396 & 1985 \\
\hline - & Bom Jesus/ RS & $\begin{array}{l}28^{\circ} 44^{\prime} 55^{\prime \prime S} \\
50^{\circ} 08^{\prime} 15^{\prime \prime} \mathrm{W}\end{array}$ & Skull and pelt & Female & UFSC-0373 & 1988 \\
\hline - & Curitiba/ PR & $\begin{array}{l}25^{\circ} 27^{\prime} 39^{\prime \prime S} \\
49^{\circ} 4^{\prime} 55 " \mathrm{~W}\end{array}$ & Vidolin et al., 2004 & - & & 1989 \\
\hline \multicolumn{7}{|c|}{ Southeast region } \\
\hline - & Paraopeba/MG & $\begin{array}{l}19^{\circ} 20^{\prime} 41^{\prime \prime} \mathrm{S} \\
44^{\circ} 28^{\prime} 40^{\prime \prime} \mathrm{W}\end{array}$ & Skull & Male & MNRJ-0381 & Prior to 1992 \\
\hline - & Anhembi/SP & $\begin{array}{l}22^{\circ} 46^{\prime} 40^{\prime \prime S} \\
48^{\circ} 17^{\prime} 20^{\prime \prime} \mathrm{W}\end{array}$ & Skull and pelt & Male & MZUSP-10351 & 1964 \\
\hline- & Anhembi/SP & $\begin{array}{l}22^{\circ} 53^{\prime 2} 29^{\prime S} \mathrm{~S} \\
48^{\circ} 14^{\prime} 41^{\prime \prime} \mathrm{W}\end{array}$ & Skull and pelt & Male & MZUSP-08878 & 1959 \\
\hline Subaúna & Mogi das Cruzes/SP & $\begin{array}{l}23^{\circ} 21^{\prime 2} 26^{\prime \prime S} \\
46^{\circ} 10^{\prime 2} 27^{\prime \prime} \mathrm{W}\end{array}$ & Skull and pelt & Male & MZUSP-27764 & 1970 \\
\hline - & Boa Esperança do Sul/ SP & $\begin{array}{l}21^{\circ} 41^{\prime 2} 23^{\prime \prime S} \\
48^{\circ} 38^{\prime} 32^{\prime \prime W}\end{array}$ & Skull and pelt & Female & MZUSP-10467 & 1964 \\
\hline - & Anhembi/SP & $\begin{array}{l}22^{\circ} 50^{\prime} 31^{\prime \prime S} \\
48^{\circ} 01^{\prime} 01^{\prime \prime} \mathrm{W}\end{array}$ & Skull and pelt & Male & MZUSP-09418 & 1961 \\
\hline - & Valparaíso/ SP & $\begin{array}{l}20^{\circ} 49^{\prime} 10^{\prime \prime S} \\
51^{\circ} 30^{\prime} 57^{\prime \prime W}\end{array}$ & Skull & Male & MZUSP-03801 & 1932 \\
\hline - & Anhembi/SP & $\begin{array}{l}22^{\circ} 41^{\prime} 08^{\prime \prime S} \\
47^{\circ} 58^{\prime} 19^{\prime \prime} \mathrm{W}\end{array}$ & Skull and pelt & Female & MZUSP-09010 & 1959 \\
\hline - & Anhembi/ SP & $\begin{array}{l}22^{\circ} 37^{\prime} 56^{\prime \prime S} \\
48^{\circ} 12^{\prime} 48^{\prime \prime} \mathrm{W}\end{array}$ & Skull and pelt & Female & MZUSP-09425 & 1961 \\
\hline - & Boa Esperança do Sul/ SP & $\begin{array}{l}22^{\circ} 13^{\prime} 26^{\prime \prime S} \\
48^{\circ} 23^{\prime} 57^{\prime \prime} \mathrm{W}\end{array}$ & Skull and pelt & Female & MZUSP-9811 & 1962 \\
\hline
\end{tabular}


Table 3. Continued.

\begin{tabular}{|c|c|c|c|c|c|c|}
\hline- & Anhembi/ SP & $\begin{array}{l}22^{\circ} 57^{\prime} 16^{\prime \prime S} \\
47^{\circ} 56^{\prime} 33^{\prime \prime W}\end{array}$ & Skull and pelt & Female & MZUSP-10352 & 1964 \\
\hline- & Anhembi/ SP & $\begin{array}{l}22^{\circ} 38^{\prime} 52^{\prime S} \\
48^{\circ} 26^{\prime} 11 " \mathrm{~W}\end{array}$ & Skull and pelt & Female & MZUSP-09637 & 1962 \\
\hline Serra da Cantareira & SP & $\begin{array}{l}23^{\circ} 22^{\prime} 41^{\prime \prime S} \\
46^{\circ} 40^{\prime} 33^{\prime \prime} \mathrm{W}\end{array}$ & Skull & Female & MZUSP-20935 & 1987 \\
\hline- & SP & 一 & Skull & Female & MZUSP-01637 & 1904 \\
\hline
\end{tabular}

Table 4. Records of puma occurrence in urban, exurban and suburban sites in south and southeast regions of Brazil.

\begin{tabular}{|c|c|c|c|c|c|c|}
\hline $\mathbf{S} / \mathbf{N}$ & Locality/ category & Town/State & $\begin{array}{l}\text { Approximate } \\
\text { coordinates }\end{array}$ & Type of record & Source & $\begin{array}{l}\text { Handled by } \\
\text { the author }\end{array}$ \\
\hline \multicolumn{7}{|c|}{ South region } \\
\hline 1 & Bairro Gethal/ suburban & Lages/ Santa Catarina & $\begin{array}{l}27^{\circ} 47^{\prime} 42.45 " \mathrm{~S} \\
50^{\circ} 18^{\prime} 1.66 " \mathrm{~W}\end{array}$ & Carcass & Gomes, 2008 & No \\
\hline 2 & Bairro Tributo/ exurban & Lages/ Santa Catarina & $\begin{array}{l}27^{\circ} 40^{\prime} 47.79 " S \\
50^{\circ} 18^{\prime} 16.98^{\prime \prime} \mathrm{W}\end{array}$ & Livestock depredation & This research, 2011 & Yes \\
\hline 3 & Cadeado / exurban & Lages/ Santa Catarina & $\begin{array}{l}27^{\circ} 45^{\prime} 39.97 " \mathrm{~S} \\
50^{\circ} 11^{\prime} 53.17^{\prime \prime} \mathrm{W}\end{array}$ & Road kill & Correio Lageano, 2008 & Yes \\
\hline 4 & Bairro Santa Isabel / suburban & São Joaquim/ Santa Catarina & $\begin{array}{l}28^{\circ} 16^{\prime} 44.62^{\prime \prime S} \\
49^{\circ} 57^{\prime} 36.01^{\prime \prime} \mathrm{W}\end{array}$ & Road kill & Correio Lageano, 2009 & Yes \\
\hline 5 & Bairro Bosque / suburban & Curitibanos/ Santa Catarina & $\begin{array}{l}27^{\circ} 17^{\prime} 12.33^{\prime \prime S} \\
50^{\circ} 35^{\prime} 26.31 " \mathrm{~W}\end{array}$ & Captured and translocated & Augusto, 2004 & Yes \\
\hline 6 & Bairro São Luiz / suburban & Canela/ Rio Grande do Sul & $\begin{array}{l}29^{\circ} 22^{\prime} 26.99 " \mathrm{~S} \\
50^{\circ} 48^{\prime} 18.92^{\prime \prime} \mathrm{W}\end{array}$ & Carcass (shot) & Vieira, 2009 & No \\
\hline 7 & Bairro Sta Corona/ suburban & $\begin{array}{l}\text { Caxias do Sul/ Rio Grande do } \\
\text { Sul }\end{array}$ & $\begin{array}{l}29^{\circ} 12^{\prime} 27.04 " \mathrm{~S} \\
51^{\circ} 10^{\prime} 33.97^{\prime \prime} \mathrm{W}\end{array}$ & Sighting and tracks & Victória, 2008 & No \\
\hline 8 & Rua Camélia/ urban & Corbélia/ Paraná & $\begin{array}{l}24^{\circ} 47^{\prime} 51^{\prime \prime S} \\
53^{\circ} 18^{\prime} 0^{\prime \prime} \mathrm{W}\end{array}$ & $\begin{array}{l}\text { Captured and transferred to a } \\
\text { zoo in Cascavel }\end{array}$ & Leitóles, 2011 & No \\
\hline 9 & Rua Frei Gaudêncio/ urban & Tibagi/ Paraná & $\begin{array}{l}24^{\circ} 30^{\prime} 57^{\prime \prime S} \\
50^{\circ} 24^{\prime} 34^{\prime \prime} \mathrm{W}\end{array}$ & Captured and translocated & Silva, 2011 & No \\
\hline 10 & $\begin{array}{l}\text { Rua Alberto Jackson Biyngton Júnior/ } \\
\text { urban }\end{array}$ & Altônia/ Paraná & $\begin{array}{l}23^{\circ} 52^{\prime} 1.81 " \mathrm{~S} \\
53^{\circ} 53^{\prime} 32.29^{\prime \prime} \mathrm{W}\end{array}$ & Captured and translocated & Nunes, 2008 & \\
\hline
\end{tabular}


Table 4. Continued.

\begin{tabular}{|c|c|c|c|c|c|c|}
\hline 11 & Rua Iratauá/ Vila Araponguinha & Arapongas/ Paraná & $\begin{array}{l}23^{\circ} 23^{\prime} 36 " \mathrm{~S} \\
51^{\circ} 25^{\prime} 18^{\prime \prime} \mathrm{W}\end{array}$ & Captured and translocated & Luporini, 2010 & \\
\hline \multicolumn{7}{|c|}{ Southeast region } \\
\hline 1 & Av. Carlos Rios/ suburban & $\begin{array}{l}\text { Santa Cruz do Rio Pardo/ São } \\
\text { Paulo }\end{array}$ & $\begin{array}{l}22^{\circ} 53^{\prime} 47 " \mathrm{~S} \\
49^{\circ} 36^{\prime} 52 " \mathrm{~W}\end{array}$ & Captured and translocated & Folha, 2011 & No \\
\hline 2 & Bairro Costa Azul/ urban & Avaré/ São Paulo & $\begin{array}{l}23^{\circ} 15^{\prime} 39 " \mathrm{~S} \\
48^{\circ} 59^{\prime} 20.77 " \mathrm{O}\end{array}$ & Captured and translocated & Tomazela, 2011 & No \\
\hline 3 & $\begin{array}{l}\text { Rua Capitão Oliveira Carvalho, Jardim Rincão/ } \\
\text { urban }\end{array}$ & São Paulo/ São Paulo & $\begin{array}{l}23^{\circ} 26^{\prime} 17.37 " \mathrm{~S} \\
46^{\circ} 43^{\prime} 38.18^{\prime \prime} \mathrm{W}\end{array}$ & Captured and translocated & Valota, 2011 & No \\
\hline 4 & Cosmópolis/ exurban & Campinas/ São Paulo & $\begin{array}{l}22^{\circ} 39^{\prime} 45^{\prime \prime S} \\
47^{\circ} 11^{\prime} 43^{\prime \prime} \mathrm{W}\end{array}$ & Captured and translocated & AmbienteBrasil, 2010 & No \\
\hline 5 & Jardim Panorama/ urban or suburban & Vinhedo/ São Paulo & $\begin{array}{l}22^{\circ} 59^{\prime} 12 " \mathrm{~S} \\
46^{\circ} 59^{\prime} 54^{\prime \prime} \mathrm{W}\end{array}$ & Captured and translocated & Globo, 2009 & No \\
\hline 6 & Residencial Lago Azul/ urban & Araçoiaba da Serra/ São Paulo & $\begin{array}{l}23^{\circ} 28^{\prime} 14.35 " \mathrm{~S} \\
47^{\circ} 35^{\prime} 6.87^{\prime \prime} \mathrm{W}\end{array}$ & Captured and translocated & Tomazela, 2009 & \\
\hline 7 & Rua Antônio Marinho de Carvalho Filho/ urban & Presidente Epitácio/ São Paulo & $\begin{array}{l}21^{\circ} 46^{\prime} 37.67 " \mathrm{~S} \\
52^{\circ} 77^{\prime} 21.43^{\prime \prime W}\end{array}$ & Captured and translocated & $\begin{array}{l}\text { Bonato, 2011; O Globo, } \\
2011\end{array}$ & \\
\hline 8 & Urban or suburban & Martinópolis/ São Paulo & $\begin{array}{l}22^{\circ} 9^{\prime} 1 " \mathrm{~S} \\
51^{\circ} 10^{\prime} 36^{\prime \prime} \mathrm{W}\end{array}$ & Captured and translocated & Globo, 2010a & \\
\hline 9 & Av. Tonico Lenci/ bairro Lago Azul/ urban & Franco da Rocha/ São Paulo & $\begin{array}{l}23^{\circ} 18 ' 8.74 " \mathrm{~S} \\
46^{\circ} 43^{\prime} 0.74^{\prime \prime} \mathrm{W}\end{array}$ & Captured and translocated & Spigliatti, 2011 & \\
\hline 10 & Rua José de Santana/ urban & Patos de Minas/ Minas Gerais & $\begin{array}{l}18^{\circ} 35^{\prime} 26 " S \\
46^{\circ} 30^{\prime} 54 " \mathrm{~W}\end{array}$ & Capture followed by death & Cury, 2011 & \\
\hline 11 & Urban & São Tomás de Aquino & $\begin{array}{l}20^{\circ} 46 ' 50 " \mathrm{~S} \\
47^{\circ} 5 \text { '53"W }\end{array}$ & Captured and translocated & EPTV, 2010 & \\
\hline 12 & Distrito de Bulhões/ exurban & Resende/ Rio de Janeiro & $\begin{array}{l}22^{\circ} 28^{\prime} \mathrm{S} \\
44^{\circ} 22^{\prime} \mathrm{W}\end{array}$ & Captured and translocated & Globo, 2010b & \\
\hline 13 & Capivari & Campos do Jordão/ São Paulo & $\begin{array}{l}22^{\circ} 43^{\prime} 10 " \mathrm{~S} \\
45^{\circ} 33^{\prime} 55^{\prime \prime} \mathrm{W}\end{array}$ & Video-capture & Globo, 2011 & \\
\hline
\end{tabular}


Table 5. Evidence of breeding population. Wild young pumas recorded in South and Southeast regions of Brazil.

\begin{tabular}{|c|c|c|c|c|c|}
\hline Locality & Town/State & $\begin{array}{l}\text { Approximate } \\
\text { coordinate }\end{array}$ & Type of record & Source & $\begin{array}{l}\text { Handled by the } \\
\text { author }\end{array}$ \\
\hline \multicolumn{6}{|l|}{ South Region } \\
\hline RPPN Caraguatá & Antônio Carlos & $\begin{array}{l}27^{\circ} 27^{\prime} 13^{\prime \prime S} \\
48^{\circ} 57^{\prime} 01^{\prime \prime W}\end{array}$ & Camera-trap & $\begin{array}{l}\text { Graipel, ME, } \\
2010\end{array}$ & no \\
\hline Alto Palmeiras & Rio dos Cedros/ SC & $\begin{array}{l}26^{\circ} 33^{\prime} 2 " \mathrm{~S} \\
49^{\circ} 22^{\prime} 56^{\prime \prime} \mathrm{W}\end{array}$ & Carcass & $\begin{array}{l}\text { Mazzolli et al., } \\
2002\end{array}$ & yes \\
\hline $\begin{array}{l}\text { Fazenda Tozo } \\
\text { (currently } \\
\text { Araucarias } \\
\text { National Park) }\end{array}$ & Ponte Serrada/ SC & $\begin{array}{l}26^{\circ} 45^{\prime} 48.00^{\prime S} \\
51^{\circ} 54^{\prime} 13.00^{\prime W}\end{array}$ & Embryos & $\begin{array}{l}\text { Mazzolli and Da- } \\
\text { Ré, } 1988\end{array}$ & yes \\
\hline $\mathrm{Km} 21$ & Lages/ SC & $\begin{array}{l}28^{\circ} 1 ' 28^{\prime \prime S} \\
50^{\circ} 28^{\prime} 45^{\prime \prime W}\end{array}$ & $\begin{array}{l}\text { Captured young, } \\
\text { hand raised, died } \\
\text { after } 1 \text { year }\end{array}$ & $\begin{array}{l}\text { Mazzolli (pers. } \\
\text { com.) }\end{array}$ & yes \\
\hline $\begin{array}{l}\text { Fazenda Três } \\
\text { Capões }\end{array}$ & Lages/SC & $\begin{array}{l}28^{\circ} 12^{\prime} 47^{\prime \prime S} \\
50^{\circ} 20^{\prime} 52^{\prime \prime W}\end{array}$ & Photograh & $\begin{array}{l}\text { Pozenatto } \\
\text { (photograph), } \\
2011\end{array}$ & yes \\
\hline $\begin{array}{l}\text { Fazenda Monte } \\
\text { Alegre }\end{array}$ & Telêmaco Borba/ PR & $\begin{array}{l}24^{\circ} 15^{\prime} 27.93^{\prime \prime S} \\
50^{\circ} 33^{\prime} 8.62^{\prime \prime W}\end{array}$ & $\begin{array}{l}\text { Captured female } \\
\text { and yearling; } \\
\text { young captured } \\
\text { and hand raised }\end{array}$ & $\begin{array}{l}\text { Mazzolli, 2000, } \\
2010\end{array}$ & yes \\
\hline $\begin{array}{l}\text { Flona São } \\
\text { Francisco de } \\
\text { Paula }\end{array}$ & $\begin{array}{l}\text { São Francisco de } \\
\text { Paula }\end{array}$ & $\begin{array}{l}29^{\circ} 25^{\prime} 45^{\prime \prime S} \\
50^{\circ} 23^{\prime} 41 " \mathrm{~W}\end{array}$ & Camera-trap & $\begin{array}{l}\text { Marques and } \\
\text { Ramos, } 2003\end{array}$ & no \\
\hline \multicolumn{6}{|l|}{ Southeast region } \\
\hline $\begin{array}{l}\text { Estrada Córrego } \\
\text { Borboleta } \\
\text { (Guararapes) }\end{array}$ & $\begin{array}{l}\text { Guararapes and } \\
\text { Valparaíso/ SP }\end{array}$ & $\begin{array}{l}21^{\circ} 14^{\prime} 44^{\prime \prime S} \\
50^{\circ} 45^{\prime} 15^{\prime \prime W}\end{array}$ & Capture & Gomes, 2006 & no \\
\hline $\begin{array}{l}\text { Juréia-Itatins } \\
\text { Ecological Station }\end{array}$ & Iguape/ SP & $\begin{array}{l}24^{\circ} 25^{\prime} \mathrm{S} \\
47^{\circ} 20^{\prime} \mathrm{W}\end{array}$ & Sighting & $\begin{array}{l}\text { Martins et al., } \\
2008\end{array}$ & no \\
\hline $\begin{array}{l}\text { Fazenda } \\
\text { Samambaia }\end{array}$ & Promissão/ SP & $\begin{array}{l}21^{\circ} 35^{\prime} 8 " \mathrm{~S} \\
49^{\circ} 58^{\prime} 35^{\prime \prime W}\end{array}$ & Capture & $\begin{array}{l}\text { Correio de Lins, } \\
2006\end{array}$ & no \\
\hline $\begin{array}{l}\text { Northeast São } \\
\text { Paulo }\end{array}$ & $\begin{array}{l}\text { Luis Antônio and } \\
\text { Santa Rita do Passa } \\
\text { Quatro/ SP }\end{array}$ & $\begin{array}{l}22^{\circ} 30^{\prime} \mathrm{S} \\
48^{\circ} 00^{\prime} \mathrm{W}\end{array}$ & Feacal DNA & Miotti et al., 2011 & no \\
\hline
\end{tabular}

